\title{
Evolutionary and Functional Implications of Incisor Enamel Microstructure Diversity in Notoungulata (Placentalia, Mammalia)
}

\author{
Andréa Filippo ${ }^{1}$ - Daniela C. Kalthoff ${ }^{2}$ (D) $\cdot$ Guillaume Billet $^{1} \cdot$ Helder Gomes Rodrigues $^{1,3,4}$
}

Published online: 13 March 2019

(C) The Author(s) 2019

\begin{abstract}
Notoungulates are an extinct clade of South American mammals, comprising a large diversity of body sizes and skeletal morphologies, and including taxa with highly specialized dentitions. The evolutionary history of notoungulates is characterized by numerous dental convergences, such as continuous growth of both molars and incisors, which repeatedly occurred in latediverging families to counter the effects of abrasion. The main goal of this study is to determine if the acquisition of high-crowned incisors in different notoungulate families was accompanied by significant and repeated changes in their enamel microstructure. More generally, it aims at identifying evolutionary patterns of incisor enamel microstructure in notoungulates. Fifty-eight samples of incisors encompassing 21 genera of notoungulates were sectioned to study the enamel microstructure using a scanning electron microscope. We showed that most Eocene taxa were characterized by an incisor schmelzmuster involving only radial enamel. Interestingly, derived schmelzmusters involving the presence of Hunter-Schreger bands (HSB) and of modified radial enamel occurred in all four late-diverging families, mostly in parallel with morphological specializations, such as crown height increase. Despite a high degree of homoplasy, some characters detected at different levels of enamel complexity (e.g., labial versus lingual sides, upper versus lower incisors) might also be useful for phylogenetic reconstructions. Comparisons with perissodactyls showed that notoungulates paralleled equids in some aspects related to abrasion resistance, in having evolved transverse to oblique HSB combined with modified radial enamel and high-crowned incisors.
\end{abstract}

Keywords Notoungulata $\cdot$ Hypsodonty $\cdot$ Incisor $\cdot$ Enamel microstructure $\cdot$ Phylogeny

Daniela C. Kalthoff

daniela.kalthoff@nrm.se

1 Centre de Recherche en Paléontologie - Paris (CR2P), UMR CNRS 7207, CP38, Muséum national d'Histoire naturelle, Sorbonne Université, 8 rue Buffon, 75005 Paris, France

2 Department of Zoology, Swedish Museum of Natural History, Box 50007, SE-104 05 Stockholm, Sweden

3 Mécanismes adaptatifs et évolution (MECADEV), UMR 7179, CNRS, Funevol team, Muséum National d'Histoire Naturelle, 55 rue Buffon, Bat. Anatomie Comparée, CP 55, 75005 Paris Cedex 5 , France

4 Present address: Institut des Sciences de l'Evolution de Montpellier, CNRS, IRD, Cc 064, Université Montpellier, place Eugène Bataillon, 34095 Montpellier Cedex 5, France

\section{Introduction}

Notoungulates constitute an extinct clade of South American ungulates showing a wide range of skeletal and cranial shapes that are in some aspects reminiscent of rhinos, horses, and even rabbits or rodents, but for which ecological affinities need to be more accurately understood (Scott 1932, 1937; Simpson 1980; Bond et al. 1995; Reguero and Prevosti 2010; Cassini and Vizcaíno 2012; Giannini and GarcíaLópez 2013; Croft 2016). Notoungulates evolved in changing geological and environmental contexts in South America from the late Paleocene to the Pleistocene-Holocene transition, a phenomenon that has been abundantly analyzed and commented (e.g., Pascual and Odreman Rivas 1971; Cifelli 1985; Pascual and Ortiz-Jaureguizar 1990; MacFadden et al. 1994; Croft 2001; Ortiz-Jaureguizar and Cladera 2006; Strömberg et al. 2013; Dunn et al. 2015; Kohn et al. 2015). The longest-lived Neogene families of notoungulates, i.e., the 
Toxodontidae, Interatheriidae, Mesotheriidae, and Hegetotheriidae, repeatedly evolved an impressive series of dental innovations, involving prolonged to continuous growth of the entire dentition (i.e., hypsodonty to hypselodonty; Billet et al. 2009; Madden 2015), and fast eruption of the entire set of cheek teeth (Gomes Rodrigues et al. 2017). The potential ecological and biological correlates of the precocious crown height increases when compared with other euungulates (i.e., more than 10 million years before their appearance in Perissodactyla and Artiodactyla) have received much attention (e.g., Stebbins 1981; Flynn and Wyss 1998; Jacobs et al. 1999; MacFadden 2000; Croft and Weinstein 2008; Croft et al. 2008; Townsend and Croft 2008; Billet et al. 2009; Gomes Rodrigues et al. 2017). The hypothesis of a repeated evolution of this dental innovation in increasingly arid environments, especially in Patagonia from the middle Eocene onward, remains intensively discussed (e.g., Madden 2015; Dunn et al. 2015; Kohn et al. 2015) and its functional implication remains to be determined.

Ever-growing and large incisors count among the widespread dental innovations within notoungulates. A significant crown height increase of incisors is also known in some other mammalian clades, such as elephants, hippos, hyraxes, rodents, lagomorphs, or some marsupials (e.g., Koenigswald 2011; Renvoisé and Michon 2014), in which it is often viewed as a major functional innovation. However, the functional and ecological significance of the convergent evolution of highcrowned incisors in notoungulates remains to be more precisely understood. The analysis of incisor enamel microstructure can provide information on biomechanical aspects. As dental enamel microstructure displays highly complex patterns in mammals, it can also provide information on phylogenetic affinities (Korvenkontio 1934; Koenigswald and Clemens 1992; Koenigswald et al. 1993; Clemens 1997). To date, incisor and molar enamel microstructure have been investigated in numerous groups of hoofed mammals (Euungulata and Paenungulata; e.g., Pfretzschner 1993; Koenigswald et al. 2011; Alloing-Seguier et al. 2014; Tabuce et al. 2017). However, microstructural characteristics of the dental enamel in notoungulate incisors remain understudied, because the rare studies have focused almost exclusively on molars (Pfretzschner 1992; Maas 1997; Lindenau 2005).

Here, we aim at studying the variations of incisor enamel microstructure in notoungulates to better characterize their convergent evolution and their potential ecological significance. The description of the different schmelzmusters (i.e., $3 \mathrm{D}$ arrangement of enamel types) observed in the upper and lower incisors of an extensive sample of notoungulate taxa first documents the microstructural diversity and its potential function in relation to the shape and mode of growth of these teeth. An evolutionary scenario for several selected microstructural traits is also proposed and discussed based on parsimonious reconstructions of character evolution.
Phylogenetic and morphofunctional implications are further discussed by comparing with notougulates' hypothesized closest extant ungulate relatives, the perissodactyls (rhinos, horses, tapirs; Buckley 2015; Welker et al. 2015), and some of their extant morphological analogues regarding their masticatory apparatus, such as the rodents (Simpson 1980; Reguero and Prevosti 2010).

\section{Material and Methods}

\section{Material Examined}

Fifty-eight samples of incisors representing 21 genera of notoungulates were investigated. They were collected in the MNHN (Paris, France), the MACN (Buenos Aires, Argentina), and the MLP (La Plata, Argentina; Table 1). These samples include genera from the Eocene to Pleistocene, put in a temporal and composite phylogenetical framework (based on data from Nasif et al. 2000; Reguero and Prevosti 2010; Billet 2011; Woodburne et al. 2014; Shockey et al. 2016). For many genera, both upper and lower incisors from different loci were sampled, because of the important size range of incisors observed in many notoungulate genera (see Table 1). Moreover, significant differences of schmelzmuster were reported between upper and lower incisors in mammals, especially rodents (Kalthoff 2000). For some samples, identification at the species level was not possible; therefore, we provide only generic identification for all sampled specimens (referred with "cf." for some generic identifications). Additional data for upper incisors of Adinotherium and Mesotherium were taken from Lindenau (2005).

\section{Institutional Abbreviations}

MACN, Museo Argentino de Ciencias Naturales "Bernardino Rivadavia," Buenos Aires, Argentina; MLP, Museo de La Plata, La Plata, Argentina; MNHN, Muséum National d'Histoire Naturelle, Paris, France; STIPB-KOE, enamel collection of the Steinmann Institute, Department of Palaeontology of the University of Bonn, Germany.

\section{Enamel Microstructure Abbreviations}

EDJ, enamel dentine junction; HSB, Hunter-Schreger band(s); IPM, interprismatic matrix; IRE, inner radial enamel; OES, outer enamel surface; ORE, outer radial enamel. For a comprehensive glossary of enamel terms, please refer to Koenigswald and Sander (1997). 
Table 1 List of collected dental specimens of notoungulates

\begin{tabular}{|c|c|c|c|c|c|c|c|}
\hline Family & Species & Incisor & Crown height & $\begin{array}{l}\text { Mesiodistal } \\
\text { length (in mm) }\end{array}$ & Number of specimen & Locality & Age (SALMA) \\
\hline \multirow[t]{2}{*}{ Notostylopidae } & \multirow[t]{2}{*}{ Notostylops sp. } & I1 & Brachydont & 4.1 & MNHN.F.CAS 646 & $\begin{array}{l}\text { Casamayor beds } \\
\text { (Argentina) }\end{array}$ & $\begin{array}{l}\text { Middle Eocene } \\
\text { (Barrancan) }\end{array}$ \\
\hline & & i1 & Brachydont & 2.4 & MNHN.F.CAS 562 & $\begin{array}{l}\text { Casamayor beds } \\
\text { (Argentina) }\end{array}$ & $\begin{array}{l}\text { Middle Eocene } \\
\text { (Barrancan) }\end{array}$ \\
\hline Pyrotheriidae & Pyrotherium sp. & I or i & Hypselodont & 24.4 & MNHN.F.DES 1077 & $\begin{array}{r}\text { Deseado beds } \\
\text { (Argentina) }\end{array}$ & $\begin{array}{l}\text { Late Oligocene } \\
\text { (Deseadan) }\end{array}$ \\
\hline \multirow[t]{5}{*}{ "Isotemnidae" } & \multirow[t]{2}{*}{ cf. Thomashuxleya } & I1 & Brachydont & 11.9 & MNHN.F.CAS 874 & $\begin{array}{l}\text { Casamayor beds } \\
\text { (Argentina) }\end{array}$ & $\begin{array}{l}\text { Middle Eocene } \\
\text { (Barrancan) }\end{array}$ \\
\hline & & I3 & Brachydont & 17.9 & MNHN.F.CAS 865 & $\begin{array}{l}\text { Casamayor beds } \\
\text { (Argentina) }\end{array}$ & $\begin{array}{l}\text { Middle Eocene } \\
\text { (Barrancan) }\end{array}$ \\
\hline & \multirow[t]{3}{*}{ cf. Pleurostylodon } & dI1 & Brachydont & 7.7 & MNHN.F.CAS 398 & $\begin{array}{l}\text { Casamayor beds } \\
\text { (Argentina) }\end{array}$ & $\begin{array}{l}\text { Middle Eocene } \\
\text { (Barrancan) }\end{array}$ \\
\hline & & i1 or i2 & Brachydont & 3.9 & MNHN.F.CAS 2709 & $\begin{array}{l}\text { Casamayor beds } \\
\text { (Argentina) }\end{array}$ & $\begin{array}{l}\text { Middle Eocene } \\
\text { (Barrancan) }\end{array}$ \\
\hline & & i2 or i3 & Brachydont & 5.4 & MNHN.F.CAS 395 & $\begin{array}{l}\text { Casamayor beds } \\
\text { (Argentina) }\end{array}$ & $\begin{array}{l}\text { Middle Eocene } \\
\text { (Barrancan) }\end{array}$ \\
\hline \multirow[t]{3}{*}{ Leontiniidae } & \multirow[t]{3}{*}{ Leontinia sp. } & I1 & $\begin{array}{l}\text { Slightly } \\
\text { hypsodont }\end{array}$ & 12.5 & MNHN.F.DES 524 & $\begin{array}{r}\text { Deseado beds } \\
\text { (Argentina) }\end{array}$ & $\begin{array}{l}\text { Late Oligocene } \\
\quad \text { (Deseadan) }\end{array}$ \\
\hline & & $\mathrm{I} 2$ & $\begin{array}{l}\text { Slightly } \\
\text { hypsodont }\end{array}$ & 19.7 & MNHN.F.DES 441 & $\begin{array}{r}\text { Deseado beds } \\
\text { (Argentina) }\end{array}$ & $\begin{array}{l}\text { Late Oligocene } \\
\text { (Deseadan) }\end{array}$ \\
\hline & & i3 & $\begin{array}{l}\text { Slightly } \\
\text { hypsodont }\end{array}$ & 13 & MNHN.F.DES 568 & $\begin{array}{r}\text { Deseado beds } \\
\text { (Argentina) }\end{array}$ & $\begin{array}{l}\text { Late Oligocene } \\
\text { (Deseadan) }\end{array}$ \\
\hline \multirow[t]{4}{*}{ "Notohippidae" } & \multirow[t]{4}{*}{ Eurygenium sp. } & I1 & Hypsodont & 8.9 & MNHN.F.SAL 1046 & Salla (Bolivia) & $\begin{array}{l}\text { Late Oligocene } \\
\text { (Deseadan) }\end{array}$ \\
\hline & & $\mathrm{I} 2$ & Hypsodont & 7.3 & MNHN.F.SAL 1047 & Salla (Bolivia) & $\begin{array}{l}\text { Late Oligocene } \\
\text { (Deseadan) }\end{array}$ \\
\hline & & i1 & Hypsodont & 6.1 & MNHN.F.SAL 1048 & Salla (Bolivia) & $\begin{array}{l}\text { Late Oligocene } \\
\text { (Deseadan) }\end{array}$ \\
\hline & & i2 & Hypsodont & 6.3 & MNHN.F.SAL 1048 & Salla (Bolivia) & $\begin{array}{l}\text { Late Oligocene } \\
\text { (Deseadan) }\end{array}$ \\
\hline \multirow[t]{9}{*}{ Toxodontidae } & \multirow[t]{3}{*}{ Adinotherium sp. } & i1 & Hypsodont & 11.2 & $\begin{array}{l}\text { MACN A-5367 } \\
\quad \text { (STIPB-KOE3415) }\end{array}$ & & $\begin{array}{l}\text { Early Miocene } \\
\quad \text { (Santacrucian) }\end{array}$ \\
\hline & & i2 & Hypsodont & 12.8 & $\begin{array}{l}\text { MACN A-5368 } \\
\quad \text { (STIPB-KOE3417) }\end{array}$ & & $\begin{array}{l}\text { Early Miocene } \\
\quad \text { (Santacrucian) }\end{array}$ \\
\hline & & i3 & Hypsodont & 14.0 & $\begin{array}{l}\text { MACN A-11730 } \\
\quad \text { (STIPB-KOE3419) }\end{array}$ & & $\begin{array}{l}\text { Early Miocene } \\
\quad \text { (Santacrucian) }\end{array}$ \\
\hline & \multirow[t]{3}{*}{ Nesodon sp. } & I1 & Hypsodont & 30.2 & $\begin{array}{l}\text { MACN A-11167 } \\
\text { (STIPB-KOE3422) }\end{array}$ & $\begin{array}{l}\text { Santa Cruz Prov. } \\
\text { (Argentina) }\end{array}$ & $\begin{array}{l}\text { Early Miocene } \\
\quad \text { (Santacrucian) }\end{array}$ \\
\hline & & $\mathrm{I} 2$ & Hypsodont & 20.6 & $\begin{array}{l}\text { MACN A-11167 } \\
\quad \text { (STIPB-KOE3421) }\end{array}$ & $\begin{array}{l}\text { Santa Cruz Prov. } \\
\text { (Argentina) }\end{array}$ & $\begin{array}{l}\text { Early Miocene } \\
\quad \text { (Santacrucian) }\end{array}$ \\
\hline & & i3 & Hypsodont & 23.9 & $\begin{array}{l}\text { MACN A-11167 } \\
\quad \text { (STIPB-KOE3420) }\end{array}$ & $\begin{array}{l}\text { Santa Cruz Prov. } \\
\text { (Argentina) }\end{array}$ & $\begin{array}{l}\text { Early Miocene } \\
\quad \text { (Santacrucian) }\end{array}$ \\
\hline & \multirow[t]{3}{*}{ Toxodon sp. } & I1 & Hypselodont & 50.6 & $\begin{array}{l}\text { MLP 52-IX-29-81 } \\
\quad \text { (STIPB-KOE3402) }\end{array}$ & $\begin{array}{l}\text { Buenos Aires } \\
\text { Prov. } \\
\text { (Argentina) }\end{array}$ & $\begin{array}{l}\text { Late Pleistocene } \\
\quad \text { (Lujanian) }\end{array}$ \\
\hline & & I1 & Hypselodont & 60.8 & $\begin{array}{l}\text { MLP P.63 } \\
\quad \text { (STIPB-KOE3401) }\end{array}$ & $\begin{array}{l}\text { Buenos Aires } \\
\text { Prov. } \\
\text { (Argentina) }\end{array}$ & $\begin{array}{l}\text { Late Pleistocene } \\
\text { (Lujanian) }\end{array}$ \\
\hline & & i1 & Hypselodont & 37.2 & $\begin{array}{l}\text { MLP 12-1204 } \\
\quad \text { (STIPB-KOE3403) }\end{array}$ & $\begin{array}{l}\text { Buenos Aires } \\
\text { Prov. } \\
\text { (Argentina) }\end{array}$ & $\begin{array}{l}\text { Late Pleistocene } \\
\text { (Lujanian) }\end{array}$ \\
\hline \multirow[t]{2}{*}{$\begin{array}{l}\text { Early diverging } \\
\text { Typotheria }\end{array}$} & \multirow[t]{2}{*}{ cf. Oldfieldthomasia } & I1 & Brachydont & 7.3 & MNHN.F.CAS 2710 & $\begin{array}{l}\text { Casamayor beds } \\
\text { (Argentina) }\end{array}$ & $\begin{array}{l}\text { Middle Eocene } \\
\text { (Barrancan) }\end{array}$ \\
\hline & & $\mathrm{I} 2$ or I 3 & Brachydont & 4.8 & MNHN.F.CAS 2711 & $\begin{array}{l}\text { Casamayor beds } \\
\text { (Argentina) }\end{array}$ & $\begin{array}{l}\text { Middle Eocene } \\
\text { (Barrancan) }\end{array}$ \\
\hline
\end{tabular}


Table 1 (continued)

\begin{tabular}{|c|c|c|c|c|c|c|c|}
\hline Family & Species & Incisor & Crown height & $\begin{array}{l}\text { Mesiodistal } \\
\text { length (in mm) }\end{array}$ & Number of specimen & Locality & Age (SALMA) \\
\hline & & i1 & Brachydont & 3.0 & MNHN.F.CAS 403 & $\begin{array}{l}\text { Casamayor beds } \\
\text { (Argentina) }\end{array}$ & $\begin{array}{l}\text { Middle Eocene } \\
\text { (Barrancan) }\end{array}$ \\
\hline & & i2 or i3 & Brachydont & 5.2 & MNHN.F.CAS 408 & $\begin{array}{l}\text { Casamayor beds } \\
\text { (Argentina) }\end{array}$ & $\begin{array}{l}\text { Middle Eocene } \\
\text { (Barrancan) }\end{array}$ \\
\hline \multirow[t]{12}{*}{ Interatheriidae } & cf. Notopithecus & $\mathrm{I} 1$ or $\mathrm{I} 3$ & Brachydont & 2.5 & MNHN.F.CAS 2712 & $\begin{array}{l}\text { Casamayor beds } \\
\text { (Argentina) }\end{array}$ & $\begin{array}{l}\text { Middle Eocene } \\
\text { (Barrancan) }\end{array}$ \\
\hline & & i1 or i2 & Brachydont & 3.1 & MNHN.F.CAS 2713 & $\begin{array}{l}\text { Casamayor beds } \\
\text { (Argentina) }\end{array}$ & $\begin{array}{l}\text { Middle Eocene } \\
\text { (Barrancan) }\end{array}$ \\
\hline & & i3 & Brachydont & 3.4 & MNHN.F.CAS 417 & $\begin{array}{l}\text { Casamayor beds } \\
\text { (Argentina) }\end{array}$ & $\begin{array}{l}\text { Middle Eocene } \\
\text { (Barrancan) }\end{array}$ \\
\hline & Protypotherium sp. & I1 & Hypsodont & 5.8 & $\begin{array}{l}\text { MACN A-9650 } \\
\quad \text { (STIPB-KOE3407) }\end{array}$ & $\begin{array}{l}\text { Santa Cruz Prov. } \\
\text { (Argentina) }\end{array}$ & $\begin{array}{l}\text { Early Miocene } \\
\quad \text { (Santacrucian) }\end{array}$ \\
\hline & & $\mathrm{I} 2$ & Hypsodont & 4.4 & $\begin{array}{l}\text { MACN A-9650 } \\
\quad(\text { STIPB-KOE3407) }\end{array}$ & $\begin{array}{l}\text { Santa Cruz Prov. } \\
\text { (Argentina) }\end{array}$ & $\begin{array}{l}\text { Early Miocene } \\
\quad(\text { Santacrucian) }\end{array}$ \\
\hline & & $\mathrm{I} 3$ & Hypsodont & 4.1 & $\begin{array}{l}\text { MACN A-9650 } \\
\quad \text { (STIPB-KOE3407) }\end{array}$ & $\begin{array}{l}\text { Santa Cruz Prov. } \\
\text { (Argentina) }\end{array}$ & $\begin{array}{l}\text { Early Miocene } \\
\quad \text { (Santacrucian) }\end{array}$ \\
\hline & & i1 & Hypsodont & 3.8 & $\begin{array}{l}\text { MACN A-3987 } \\
\quad(\text { STIPB-KOE3408) }\end{array}$ & $\begin{array}{l}\text { Santa Cruz Prov. } \\
\text { (Argentina) }\end{array}$ & $\begin{array}{l}\text { Early Miocene } \\
\quad \text { (Santacrucian) }\end{array}$ \\
\hline & & $\mathrm{i} 2$ & Hypsodont & 2.3 & $\begin{array}{l}\text { MACN A-3987 } \\
\quad(\text { STIPB-KOE3408) }\end{array}$ & $\begin{array}{l}\text { Santa Cruz Prov. } \\
\text { (Argentina) }\end{array}$ & $\begin{array}{l}\text { Early Miocene } \\
\quad \text { (Santacrucian) }\end{array}$ \\
\hline & & $i 3$ & Hypsodont & 2.3 & $\begin{array}{l}\text { MACN A-3987 } \\
\quad(\text { STIPB-KOE3408) }\end{array}$ & $\begin{array}{l}\text { Santa Cruz Prov. } \\
\text { (Argentina) }\end{array}$ & $\begin{array}{l}\text { Early Miocene } \\
\quad \text { (Santacrucian) }\end{array}$ \\
\hline & $\begin{array}{l}\text { Interatherium } \\
\text { extensus }\end{array}$ & $\mathrm{I} 1$ & Hypsodont & 3.3 & $\begin{array}{l}\text { MACN A-9735 } \\
\quad(\text { STIPB-KOE3410) }\end{array}$ & $\begin{array}{l}\text { Santa Cruz Prov. } \\
\text { (Argentina) }\end{array}$ & $\begin{array}{l}\text { Early Miocene } \\
\quad \text { (Santacrucian) }\end{array}$ \\
\hline & Interatherium sp. & i1 & Hypsodont & 2.1 & $\begin{array}{l}\text { MACN A-144-60 } \\
\quad(\text { STIPB-KOE3411) }\end{array}$ & & $\begin{array}{l}\text { Early Miocene } \\
\quad \text { (Santacrucian) }\end{array}$ \\
\hline & & $\mathrm{i} 2$ & Hypsodont & 1.9 & $\begin{array}{l}\text { MACN A-144-60 } \\
\quad(\text { STIPB-KOE3411) }\end{array}$ & & $\begin{array}{l}\text { Early Miocene } \\
\quad(\text { Santacrucian) }\end{array}$ \\
\hline \multirow[t]{7}{*}{ Mesotheriidae } & Trachytherus alloxus & $\mathrm{I} 1$ & Hypselodont & 12.9 & MNHN.F.SAL 1049 & Salla (Bolivia) & $\begin{array}{l}\text { Late Oligocene } \\
\text { (Deseadan) }\end{array}$ \\
\hline & & $\mathrm{i} 2$ & Hypselodont & 8.4 & MNHN.F.SAL 792 & Salla (Bolivia) & $\begin{array}{l}\text { Late Oligocene } \\
\text { (Deseadan) }\end{array}$ \\
\hline & $\begin{array}{l}\text { Plesiotypotherium } \\
\text { achirense }\end{array}$ & $\mathrm{I} 1$ & Hypselodont & 20.6 & MNHN.F.ACH 38 & Achiri (Bolivia) & $\begin{array}{l}\text { Late Miocene } \\
\qquad \text { (Huayquerian) }\end{array}$ \\
\hline & & i1 & Hypselodont & 11.1 & MNHN.F.ACH 37 & Achiri (Bolivia) & $\begin{array}{l}\text { Late Miocene } \\
\qquad \text { (Huayquerian) }\end{array}$ \\
\hline & & $\mathrm{i} 2$ & Hypselodont & 7.7 & MNHN.F.ACH 37 & Achiri (Bolivia) & $\begin{array}{l}\text { Late Miocene } \\
\qquad \text { (Huayquerian) }\end{array}$ \\
\hline & $\begin{array}{l}\text { Pseudotypotherium } \\
\text { sp. }\end{array}$ & I1 & Hypselodont & 25.0 & $\begin{array}{l}\text { MACN } 14817 \\
\quad(\text { STIPB-KOE3413) }\end{array}$ & $\begin{array}{c}\text { Olivos, Buenos } \\
\text { Aires Prov. } \\
\text { (Argentina) }\end{array}$ & $\begin{array}{l}\text { Middle Pleistocene } \\
\text { (Ensenadan) }\end{array}$ \\
\hline & Mesotherium sp. & i1 & Hypselodont & 21.9 & $\begin{array}{l}\text { MACN } 2104 \\
\quad(\text { STIPB-KOE3412) }\end{array}$ & Pampas Fm. & $\begin{array}{l}\text { Middle Pleistocene } \\
\text { (Ensenadan) }\end{array}$ \\
\hline \multirow[t]{5}{*}{ Hegetotheriidae } & $\begin{array}{l}\text { Hegetotherium } \\
\text { mirabile }\end{array}$ & $\mathrm{I} 1$ & Hypselodont & 7.1 & $\begin{array}{l}\text { MACN A-9910 } \\
\quad(\text { STIPB-KOE3406) }\end{array}$ & $\begin{array}{l}\text { Santa Cruz Prov. } \\
\text { (Argentina) }\end{array}$ & $\begin{array}{l}\text { Early Miocene } \\
\quad \text { (Santacrucian) }\end{array}$ \\
\hline & Hegetotherium sp. & i1 & Hypselodont & 5.1 & $\begin{array}{l}\text { MACN. A-11206 } \\
\quad(\text { STIPB-KOE3405) }\end{array}$ & $\begin{array}{l}\text { Santa Cruz Prov. } \\
\text { (Argentina) }\end{array}$ & $\begin{array}{l}\text { Early Miocene } \\
\quad \text { (Santacrucian) }\end{array}$ \\
\hline & $\begin{array}{r}\text { Paedotherium } \\
\text { bonaerense }\end{array}$ & I1 & Hypselodont & 6.6 & $\begin{array}{l}\text { MLP 52-IX-28-15 } \\
\quad(\text { STIPB-KOE3293) }\end{array}$ & $\begin{array}{l}\text { Miramar, } \\
\text { Buenos Aires } \\
\text { Prov. } \\
\text { (Argentina) }\end{array}$ & $\begin{array}{l}\text { Early Pliocene } \\
\text { (Chapadmalalan) }\end{array}$ \\
\hline & Paedotherium sp. & i1 & Hypselodont & 4.5 & $\begin{array}{l}\text { MLP 94-VI-5-3 } \\
\quad \text { (STIPB-KOE3296) }\end{array}$ & $\begin{array}{l}\text { Chapadmalal } \\
\text { Fm. }\end{array}$ & $\begin{array}{l}\text { Early Pliocene } \\
\text { (Chapadmalalan) }\end{array}$ \\
\hline & & i2 & Hypselodont & 2.6 & & & \\
\hline
\end{tabular}


Table 1 (continued)

\begin{tabular}{|c|c|c|c|c|c|c|c|}
\hline Family & Species & Incisor & Crown height & $\begin{array}{l}\text { Mesiodistal } \\
\text { length (in mm) }\end{array}$ & Number of specimen & Locality & Age (SALMA) \\
\hline & & & & & $\begin{array}{l}\text { MLP 94-VI-5-3 } \\
\text { (STIPB-KOE3296) }\end{array}$ & $\begin{array}{l}\text { Chapadmalal } \\
\text { Fm. }\end{array}$ & $\begin{array}{l}\text { Early Pliocene } \\
\quad \text { (Chapadmalalan) }\end{array}$ \\
\hline & $\begin{array}{l}\text { Tremacyllus } \\
\text { impressus }\end{array}$ & I1 & Hypselodont & 6.9 & $\begin{array}{l}\text { MLP 76-XII-3-13 } \\
\quad(\text { STIPB-KOE3291) }\end{array}$ & Quequin Salado & $\begin{array}{l}\text { Early Pliocene } \\
\text { (Montehermosea- } \\
\text { n) }\end{array}$ \\
\hline & Tremacyllus sp. & i1 & Hypselodont & 3.5 & $\begin{array}{l}\text { MLP 52-IX-27-78 } \\
\quad(\text { STIPB-KOE3292) }\end{array}$ & $\begin{array}{l}\text { Miramar, } \\
\text { Buenos Aires } \\
\text { Prov. } \\
\text { (Argentina) }\end{array}$ & $\begin{array}{l}\text { Early Pliocene } \\
\quad \text { (Chapadmalalan) }\end{array}$ \\
\hline & & i2 & Hypselodont & 2.6 & $\begin{array}{l}\text { MLP 52-IX-27-78 } \\
\quad(\text { STIPB-KOE3292) }\end{array}$ & $\begin{array}{l}\text { Miramar, } \\
\text { Buenos Aires } \\
\text { Prov. } \\
\text { (Argentina) }\end{array}$ & $\begin{array}{l}\text { Early Pliocene } \\
\quad \text { (Chapadmalalan) }\end{array}$ \\
\hline & Pachyrukhos sp. & I1 & Hypselodont & 6.7 & $\begin{array}{l}\text { MLP 73-VII-6-4 } \\
\quad \text { (STIPB-KOE3299) }\end{array}$ & $\begin{array}{l}\text { Pelcaniyeu-Rio } \\
\text { Negro }\end{array}$ & $\begin{array}{r}\text { Middle Miocene } \\
\text { (Colloncuran) }\end{array}$ \\
\hline & & i1 & Hypselodont & 3.6 & $\begin{array}{l}\text { MLP 68-I-16-2 } \\
\text { (STIPB-KOE3300) }\end{array}$ & $\begin{array}{l}\text { Santa Cruz Prov. } \\
\text { (Argentina) }\end{array}$ & $\begin{array}{l}\text { Early Miocene } \\
\quad \text { (Santacrucian) }\end{array}$ \\
\hline & & i2 & Hypselodont & 1.4 & $\begin{array}{l}\text { MLP 68-I-16-2 } \\
\quad(\text { STIPB-KOE3300) }\end{array}$ & $\begin{array}{l}\text { Santa Cruz Prov. } \\
\text { (Argentina) }\end{array}$ & $\begin{array}{l}\text { Early Miocene } \\
\quad \text { (Santacrucian) }\end{array}$ \\
\hline
\end{tabular}

Lowercase i depicts teeth from the mandible, uppercase I from the maxilla. SALMA: South American Land Mammal Age(s)

\section{Enamel Microstructure Preparation}

Specimens were embedded in polyester or epoxy resin. Longitudinal sections were performed labiolingually from the apex to the root of the incisor, whereas labiolingual transverse sections were perpendicular to the longitudinal plane (Fig. 1). Some sections were not realized due to limited sizes, intense wear, or absence of the enamel layer (Table 1). As a result, 103 sections were generated. Then, these sections were ground and polished with $1200 \mathrm{Al}_{2} \mathrm{O}_{3}$ grit powder. In order to make enamel prisms and interprismatic matrix visible, we performed phosphoric acid etching for $5 \mathrm{~s}$ and rinsed with water combined with ultrasonic cleaning. Specimens were sputter-coated with gold for 2 min and small samples were subsequently mounted on SEM stubs (Kalthoff 2000). The enamel microstructure was studied and documented with a scanning electron microscope Jeol Benchtop JCM-6000 at an acceleration voltage of $15 \mathrm{kV}$ and at magnifications from $\times 85$ to $\times 2400$. Preparations resulting from this study are deposited in the enamel collection of the Steinmann Institute (Bonn, Germany; STIPB) and in the collections of the MNHN (Paris, France).

\section{Parameters Evaluated}

The following parameters were evaluated in the description of incisor enamel microstructure (Fig. 1; Table 2; some of them are detailed on Alloing-Seguier et al. 2014):
- Mean enamel thickness; measured perpendicularly between enamel dentine junction (EDJ) and outer enamel surface (OES) on transverse section in the central part of the enamel band of the incisor (i.e., middle part of the incisor) after five measurements.

- Presence or absence of an undulated EDJ on the transverse section.

- Mean relative thickness of each layer (IRE, HSBs, and ORE) after five measurements.

- Range of HSB thickness (minimum - maximum) after five measurements.

- Aspect of HSB; we called HSB as "steady" when the width of each band keeps the same value from the inner to the outer extremities of the band, if not we considered HSBs as "variable."

- Number of prisms per HSB.

- Multiple presence or absence of HSB bifurcations; corresponds to bands of similar prism orientation that are joining or bifurcating toward the OES.

- Inclination (or angle) of HSBs at EDJ on longitudinal sections.

- Decussations of adjacent HSB; described as having a high $\left(>45^{\circ}\right)$ or low decussation angle $\left(<45^{\circ}\right)$.

- Configuration of HSB; if HSBs were clearly discernible in both longitudinal and transverse sections, we defined HSBs as "oblique"; if HSBs were only discernible in longitudinal section, we defined HSBs as "transverse."

- IPM orientation; IPM was described as "closed coats" if it surrounds the prisms, or as "interrow sheets" if it forms 

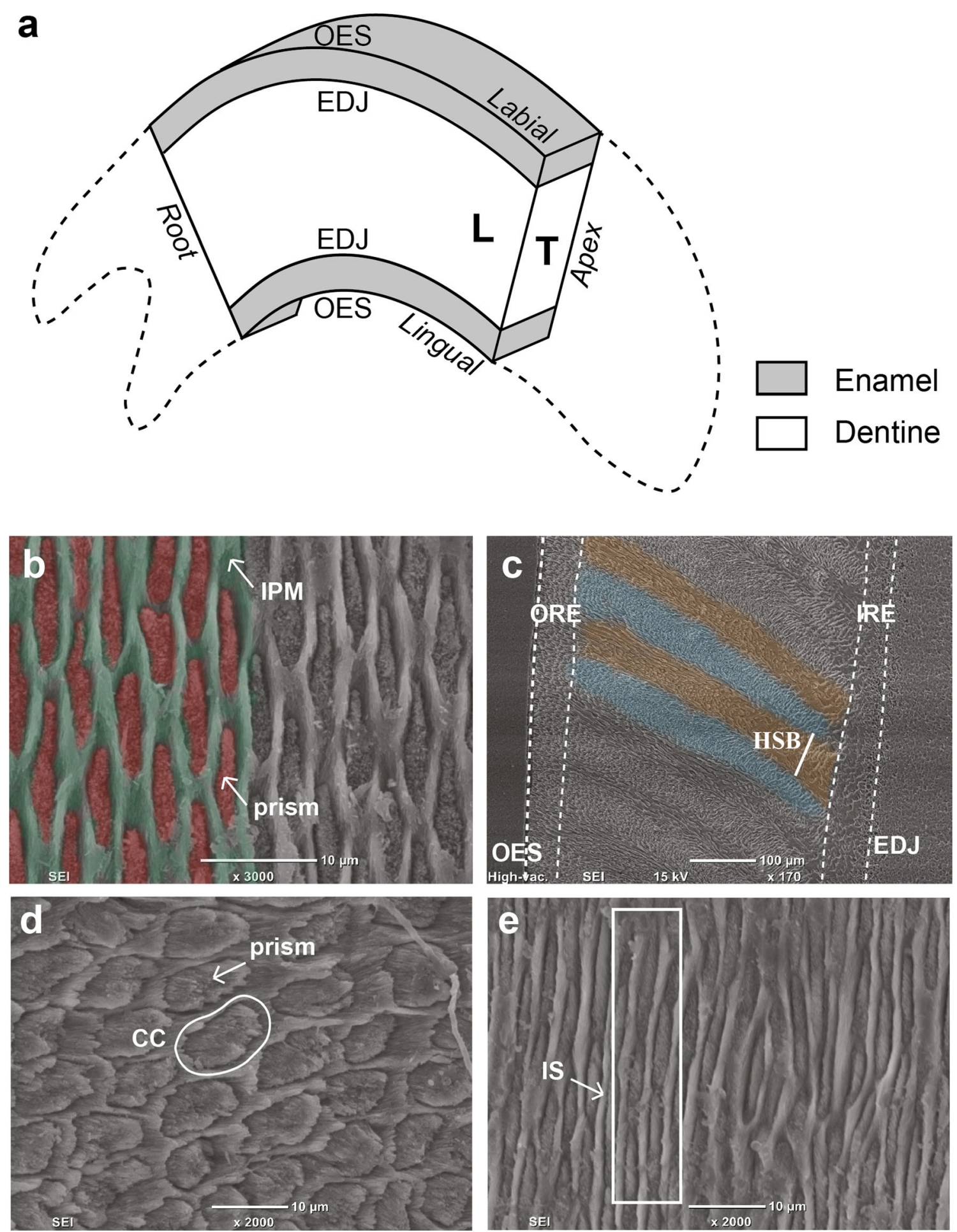

Fig. 1 a Schematic sketch of a sliced incisor portion showing the longitudinal (L) and transverse (T) section planes. EDJ: enamel dentine junction; HSB: Hunter-Schreger band(s); IPM: interprismatic matrix; IRE: inner radial enamel; OES: outer enamel surface; ORE: outer radial enamel. $\mathbf{b}$ and $\mathbf{c}$ Scanning electron micrographs showing prisms in red and IPM in green (b) and HSB in orange and blue (c): $\mathbf{b}$ Adinotherium (MACN A-5368, STIPB-KOE3417), longitudinal section of i2, labial

side; c Protypotherium (MACN A-9650, STIPB-KOE3407), transversal section of I2, labial side. $\mathbf{d}$ and $\mathbf{e}$ Scanning electron micrographs showing IPM orientation: d closed coats surrounding prisms (CC) in Leontinia (MNHN.F.DES 524), lingual side of I1, longitudinal section; e interrow sheets (IS) in Eurygenium (MNHN.F.SAL 1046), labial side of I1, transverse section 


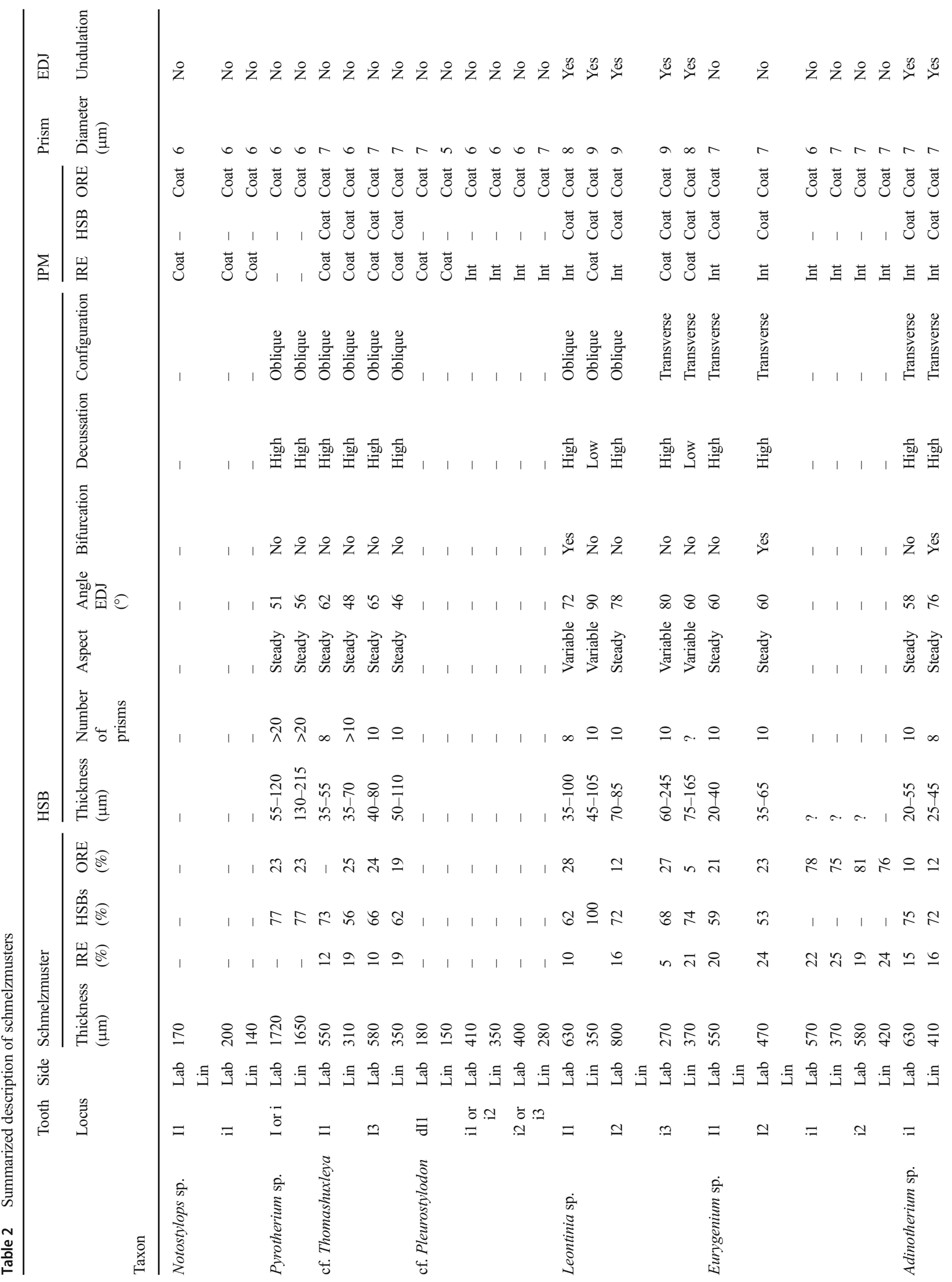




\section{穴亭

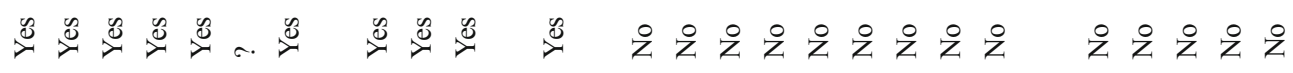 \\ 竞离 \\ 秏

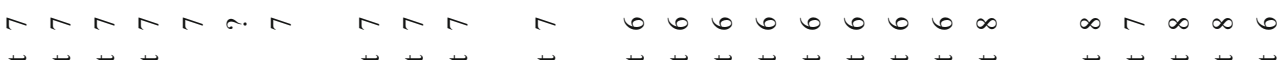

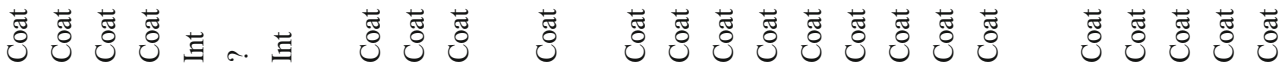

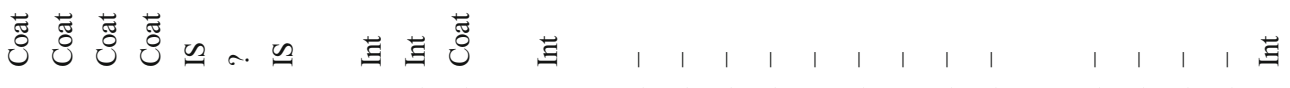

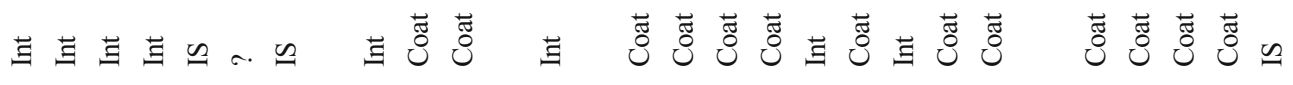

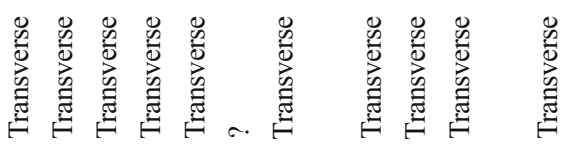 \\ $\frac{0}{0}$}

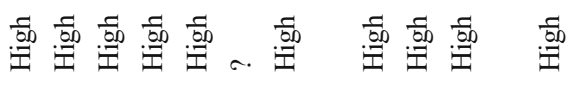

预

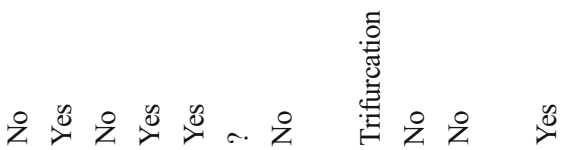

$\overrightarrow{9}$

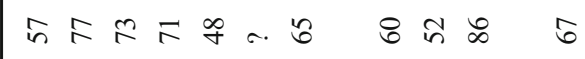

$\infty$

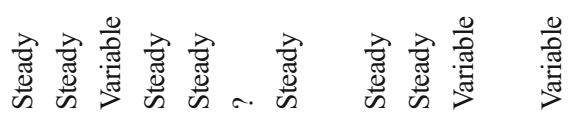

急曾主

됭

응

营 ᄋ

뙹

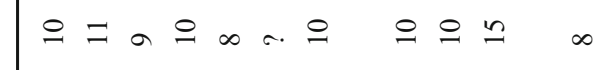

우웡 8 i

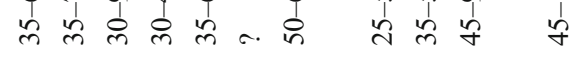

o

$\simeq \pm \stackrel{\infty}{\simeq} a \cdots \infty \quad n \circ \stackrel{\vec{T}}{\Omega}$ ते

1 1 , , \& 8 i

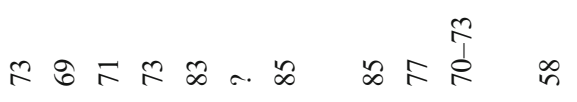

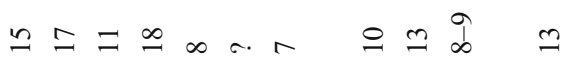

子

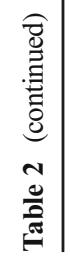

윰

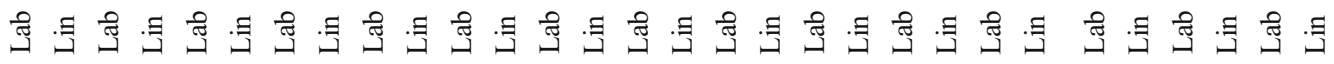

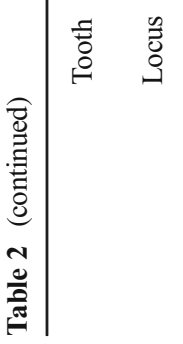

$\mid$

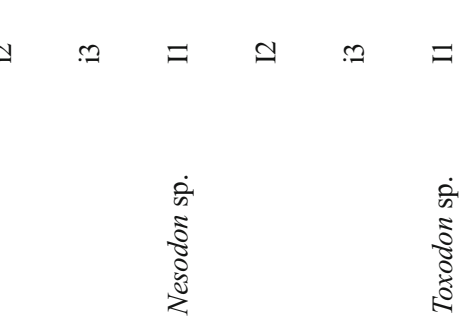

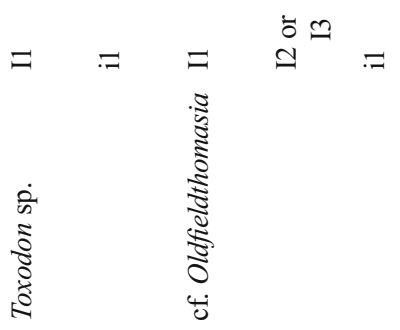

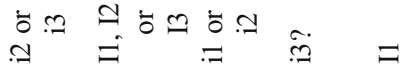




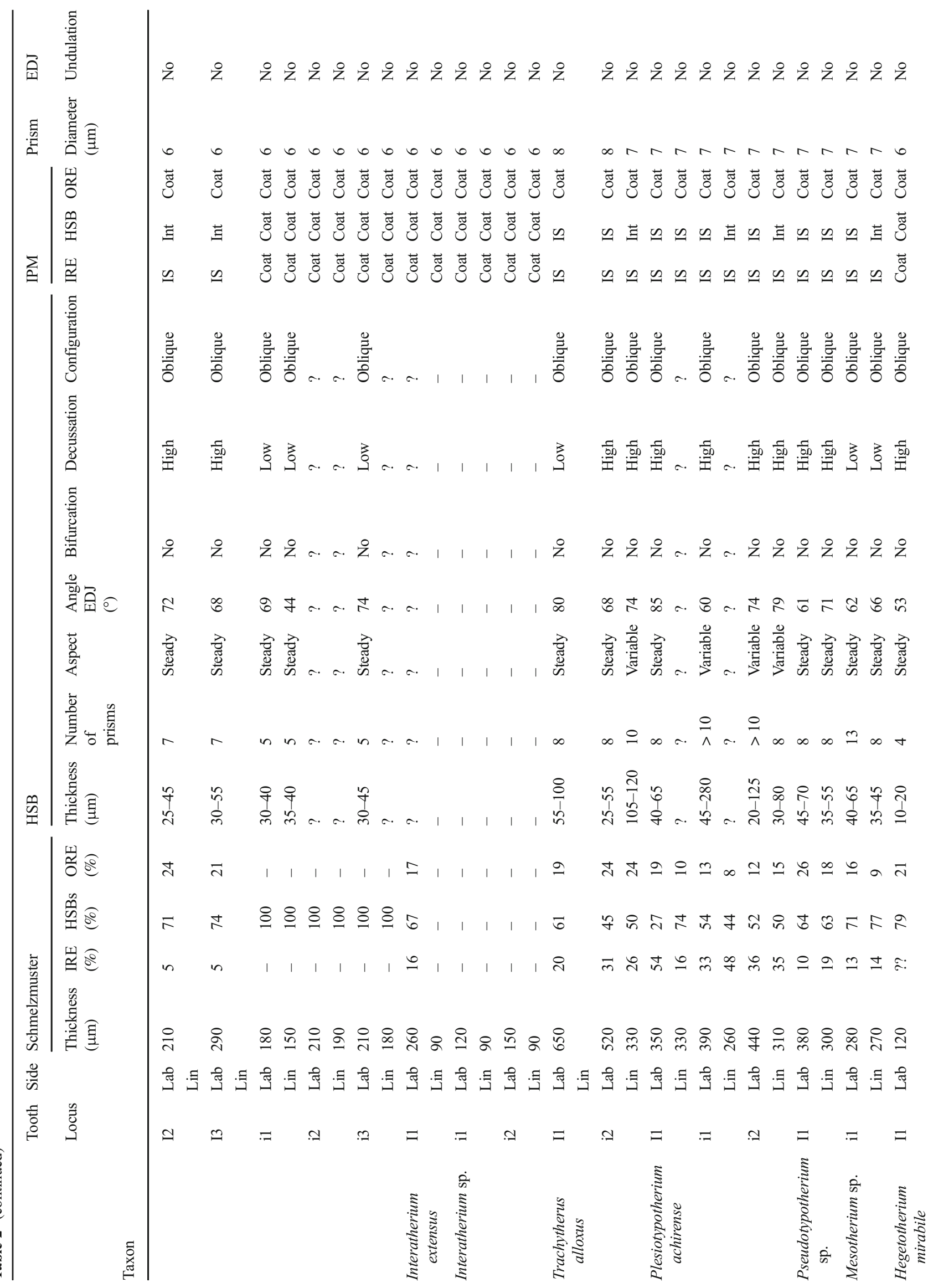




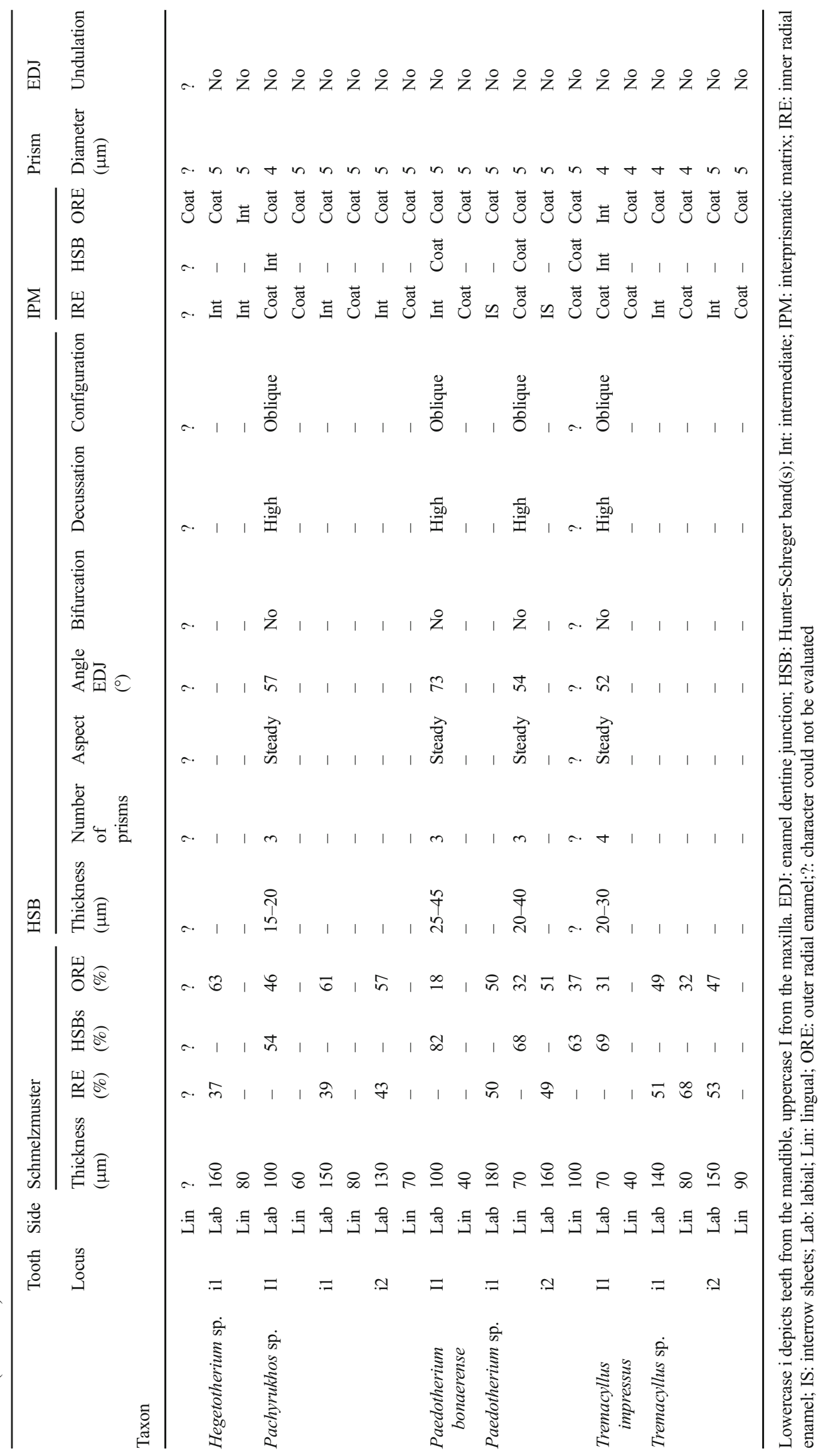


layers between rows of prisms, which characterizes a modified radial enamel. Furthermore, the IPM was described as "intermediate" if there are those two types in the same enamel layer, meaning that IPM is clearly anastomosing. The angle made by the orientation of crystallites forming the IPM with respect to the prisms is sometime difficult to measure, because the orientation of crystallites may not be clearly visible. As a result only the maximal angle was measured when possible.

- Mean prism diameter; measured in longitudinal sections; mean of five measurements.

\section{Analyses}

A parsimony reconstruction of character evolution was performed using Mesquite version 3.04 (Maddison and Maddison 2015) with a Deltran optimization (Agnarsson and Miller 2008) on a composite tree of notoungulates (from Billet 2011 and Shockey et al. 2016). This analysis was realized to trace and discuss the evolution of some characters, such as prism decussation, IPM characteristics in order to compare them with hypsodonty and body masses (data from Croft 2000; Reguero et al. 2010; Gomes Rodrigues et al. 2017). Given the uncertainty for the phylogenetic placement of Pyrotherium (e.g., Billet 2010; Muizon et al. 2015; Kramarz et al. 2017), it was tentatively located in an unresolved basal node with most notoungulates and Notostylops. Pyrotherium is herein considered as a notoungulate or a close notoungulate ally, but other analyses and intermediate Eocene fossils are needed to test this hypothesis further.

\section{Results}

\section{Notostylopidae}

Notostylops: I1, i1 (Fig. 2a, b; Table 2).

Notostylops presents enamel only on the labial side of I1, but on both sides of 11 . The enamel is $\sim 170 \mu \mathrm{m}$ thick on I1 and $\sim 140-200 \mu \mathrm{m}$ on $\mathrm{i} 1$. The enamel microstructure of Notostylops is similar on both I1 and i1, and on both labial and lingual sides concerning i1. The schmelzmuster is onelayered and exclusively represented by radial enamel. HSB are absent, but prisms are slightly oblique, and their diameter is $\sim 6 \mu \mathrm{m}$. IPM forms closed coats on the entire thickness, but it is slightly anastomosing close to the EDJ. The maximal angle between the IPM and prisms is about $25-30^{\circ}$.

\section{Pyrotheriidae}

Pyrotherium: undetermined incisor (Fig. 2c, d; Table 2).
Pyrotherium presents enamel on both sides of the incisor investigated, which display the same enamel microstructure. The enamel measures $\sim 1650-1720 \mu \mathrm{m}$ and is characterized by a two-layered schmelzmuster with ORE (23\%) and thick HSB starting at the EDJ (77\%). Prism diameter is $\sim 6 \mu \mathrm{m}$. The HSB show a key hole pattern (see Koenigswald et al. 2015), while IPM forms closed coats in the outer radial enamel. In the keyhole pattern, prisms are densely packed and IPM can be observed in some areas. Furthermore, in longitudinal section, those prisms show an arc-shaped prism sheath that is widely open to one side. HSBs (55-215 $\mu \mathrm{m}$ thick) display a more variable aspect in longitudinal section than in transverse section, where they are more steady. The maximal angle between the IPM and prisms is about $35-40^{\circ}$.

\section{Toxodontia}

\section{"Isotemnidae"}

cf. Pleurostylodon: dI1, i1 or i2, i2 or i3; cf. Thomashuxleya: I1, I3 (Fig. 2e-h; Table 2).

The specimens referred as cf. Pleurostylodon and cf. Thomashuxleya present enamel on both labial and lingual sides of upper and lower incisors. On the transverse section of upper incisors, the enamel is $\sim 310-580 \mu \mathrm{m}$ thick in cf. Thomashuxleya and $\sim 150-180 \mu \mathrm{m}$ in cf. Pleurostylodon. On lower incisors, the enamel is $\sim 280-410 \mu \mathrm{m}$ thick in cf. Pleurostylodon. Lower incisors of cf. Thomashuxleya were not available for analysis.

The enamel microstructure is very different between the two taxa. Cf. Pleurostylodon presents slightly different enamel microstructure on dI1 and lower incisors, according to the IPM arrangement, but the microstructure pattern is similar on both lingual and labial sides. dI1 is characterized by a onelayered schmelzmuster formed by radial enamel. HSBs are absent, but prisms are oblique except near the EDJ where they present a high angle with respect to the longitudinal plane. Prism diameter is $\sim 5-7 \mu \mathrm{m}$. The IPM forms closed coats, but it is slightly anastomosing close to the EDJ. On the longitudinal section, prism orientation is $60^{\circ}$ throughout the entire thickness. The enamel microstructure of $\mathrm{i} 1 / \mathrm{i} 2$ and $\mathrm{i} 2 / \mathrm{i} 3$ is similar. The schmelzmuster is one-layered and exclusively represented by radial enamel. The IPM forms closed coats near the OES and is intermediate near the EDJ. The maximal angle between the IPM and prisms is about $40-60^{\circ}$.

The enamel microstructure of cf. Thomashuxleya is similar on I1 and I3 and on their both sides. We noticed a threelayered schmelzmuster. There is radial enamel close to EDJ and the OES (10-19\% and 15-25\%), and HSBs in the middle layer $(56-73 \%)$. Prisms diameter is between $\sim 6-7 \mu \mathrm{m}$. The HSBs are generally thin (35-80 $\mu \mathrm{m}$ thick), oblique, and steady. Moreover, HSB are discernible on both longitudinal and transverse sections. The IPM forms closed coats in the 

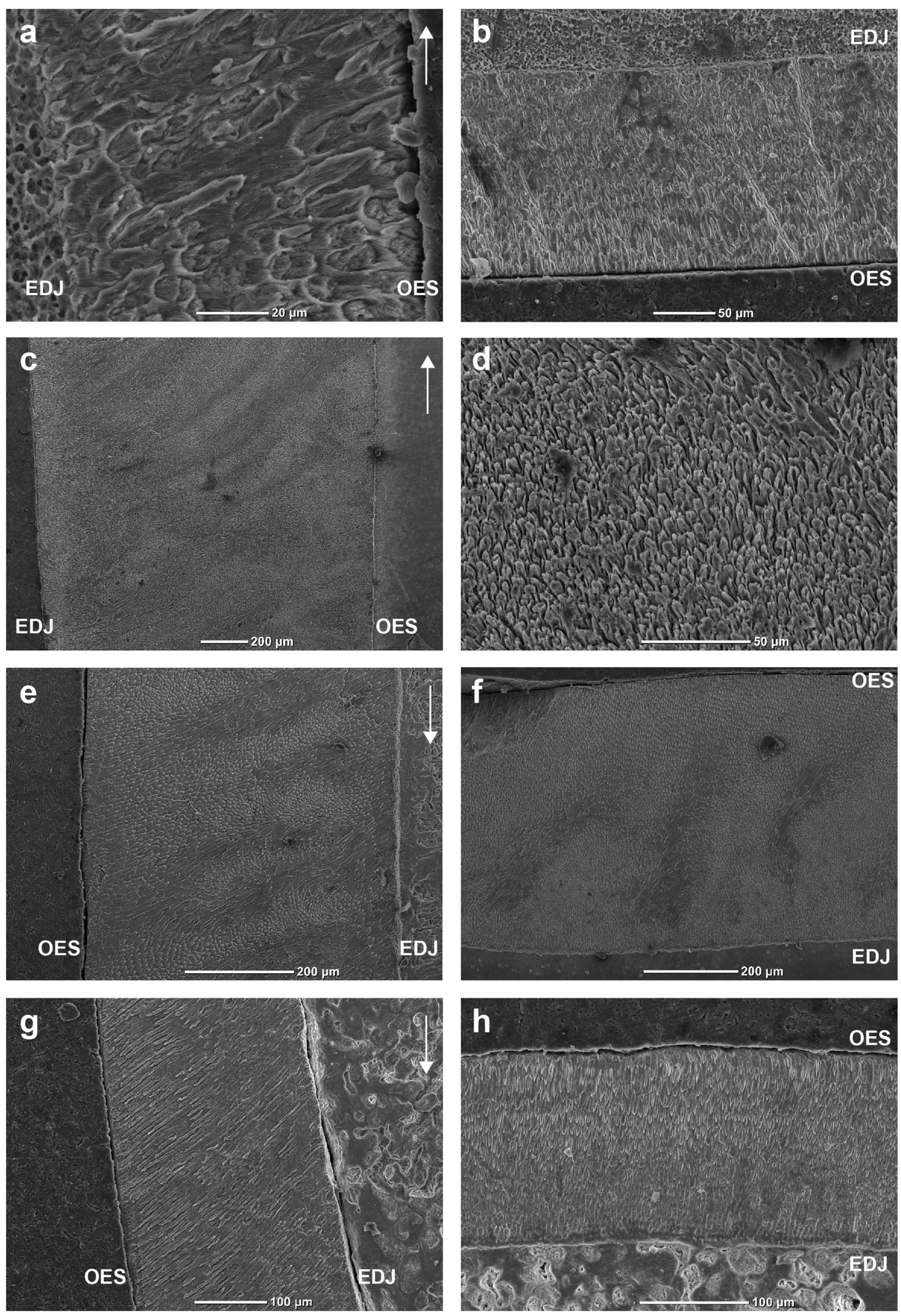
Fig. 2 Scanning electron micrographs of Notostylops, Pyrotherium, and "Isotemnidae." a and b Notostylops (MNHN.F.CAS 646), labial side of I1, longitudinal and transverse sections. c and d Pyrotherium (MNHN.F.DES 1077), labial side of I or i, longitudinal and transverse sections with focus on prisms showing a keyhole pattern. e and $\mathbf{f}$ cf. Thomashuxleya (MNHN.F.CAS 865), labial side of I3, longitudinal and transverse sections. $\mathbf{g}$ and $\mathbf{h}$ cf. Pleurostylodon (MNHN.F.CAS 395 and 398), labial side of i2-i3, longitudinal section, labial side of dI1, transverse section. EDJ: enamel dentine junction; OES: outer enamel surface. The white arrow indicates the apex of the incisor on longitudinal sections

HSB layer and in the inner and outer radial enamel. The maximal angle between the IPM and prisms is about $60-80^{\circ}$.

\section{Leontiniidae}

Leontinia: I1, I2, i3 (Fig. 3a, b; Table 2).

Leontinia presents enamel on both labial and lingual sides of I1 and i3, but only on the lingual side of I2. On the transverse section of upper incisors, the enamel is $\sim 350-800 \mu \mathrm{m}$ thick and on i3 it is $\sim 270-370 \mu \mathrm{m}$ thick. The enamel microstructure is similar in the sampled upper incisors, which are slightly different from the lower incisor. Furthermore, the enamel microstructure is also different between labial and lingual sides for upper incisors, while it is similar on both sides of i3.

The schmelzmuster of the labial side of the upper incisors is three-layered with radial enamel near the EDJ and OES (10$16 \%$ and $12-28 \%$ ) and HSBs in the middle layer (62-72\%). Prism diameter is $\sim 8-9 \mu \mathrm{m}$. The HSBs are 35-100 $\mu \mathrm{m}$ thick, and they are oblique with variable aspect. The IPM forms closed coats in the HSB and in the ORE. We observed intermediate IPM near the EDJ in the IRE. The schmelzmuster of the lingual side of I1 is one-layered and exclusively presents oblique HSBs (45-105 $\mu \mathrm{m}$ thick), which have a variable aspect. IPM forms closed coats.

The schmelzmuster of i3 is three-layered with inner (5$21 \%)$ and outer (5-27\%) radial enamel and HSB (68-74\%). Prism diameter is $\sim 8-9 \mu \mathrm{m}$. The HSBs are thick $(60-245 \mu \mathrm{m})$, and transverse. The IPM forms closed coats in the entire thickness. The EDJ is undulated.

The maximal angle between the IPM and prisms is about $40-65^{\circ}$.

\section{"Notohippidae"}

\section{Eurygenium: I1, I2, i1, i2 (Table 2).}

Eurygenium presents enamel on both sides of the lower incisors but only on the labial side of upper incisors. On the transverse section of upper incisors, the enamel is $\sim 470$ $550 \mu \mathrm{m}$ thick and on lower incisors the thickness is $\sim 370$ $580 \mu \mathrm{m}$. All upper incisors display identical schmelzmuster, but it is different from lower incisors. The enamel on lower incisors presents the same schmelzmuster on both sides.

The schmelzmuster of upper incisors is three-layered with radial enamel near the EDJ and OES (20-24\% and 21-23\%) and HSBs in-between (53-59\%). Prism diameter is $\sim 7 \mu \mathrm{m}$. The HSBs are thin $(20-65 \mu \mathrm{m})$ and transverse. On the transverse sections, prisms present a slightly wavy pattern; the HSBs are not clearly distinguishable. The IPM forms closed coats in the HSBs and near the OES. We observed intermediate IPM near the EDJ.

Lower incisors are characterized by a two-layered schmelzmuster represented exclusively by radial enamel. Prism diameter is $\sim 7 \mu \mathrm{m}$. Prisms are oblique near the EDJ and less inclined near the OES. The IPM is intermediate in the IRE and forms closed coats in the ORE.

The maximal angle between the IPM and prisms is about $55-65^{\circ}$.

\section{Toxodontidae}

Adinotherium: i1, i2, i3; Nesodon: I1, I2, i3; Toxodon: I1, i1 (Fig. 3c-h; Table 2).

The sampled toxodontids present different enamel microstructures, but the schmelzmuster is homogeneous within each genus. Nesodon and Toxodon present enamel only on the labial side of upper incisors, Adinotherium has enamel on the labial side of I1, but both on the labial and lingual side of I2 (all information for upper incisors of Adinotherium is from Lindenau 2005). Adinotherium and Nesodon present enamel on both sides of lower incisors whereas Toxodon present enamel only on the labial side.

In the upper incisors in Nesodon and Toxodon, the enamel is thick $(\sim 960-1120 \mu \mathrm{m})$. On their lower incisors, the enamel is thinner (between $\sim 320-1000 \mu \mathrm{m}$ ). The enamel microstructure is similar on upper and lower incisors of Adinotherium and Nesodon, whereas the schmelzmuster in Toxodon is different from the latter. When enamel is present on the lingual side of lower incisors, the enamel microstructure is similar to the labial side.

Upper and lower incisors of the sampled toxodontids present a three-layered schmelzmuster with radial enamel near the EDJ and OES (7-18\% and 5-29\%) and HSBs in-between (58-85\%). Prism diameter is $\sim 7 \mu \mathrm{m}$. Prisms orientation is different in the HSB compared to the IRE and ORE. Variation in the thickness of HSBs is important among Toxodontidae (Adinotherium: 20-90 $\mu \mathrm{m}$, Nesodon: 25$65 \mu \mathrm{m}$, Toxodon: 45-105 $\mu \mathrm{m})$. Aspect of HSB is generally steady in Adinotherium and Nesodon, but rather variable in Toxodon. Toxodontidae have transverse HSB, given that prisms have a wavy pattern on the transverse sections, which makes HSB difficult to discern. The IPM generally forms closed coats but tends to anastomose in the HSB and near the EDJ. More precisely, the IPM is intermediate near the 

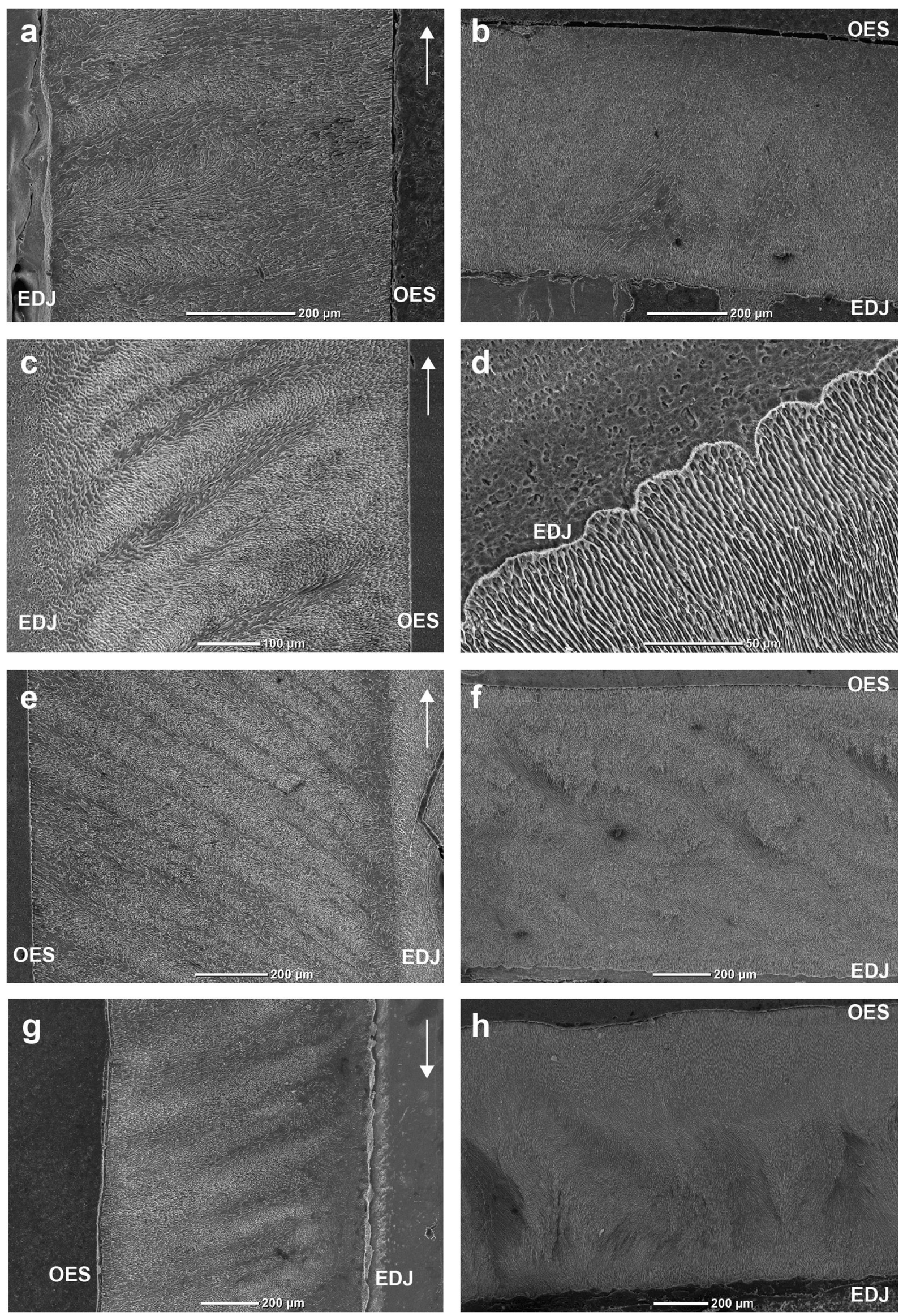

h

OES

-
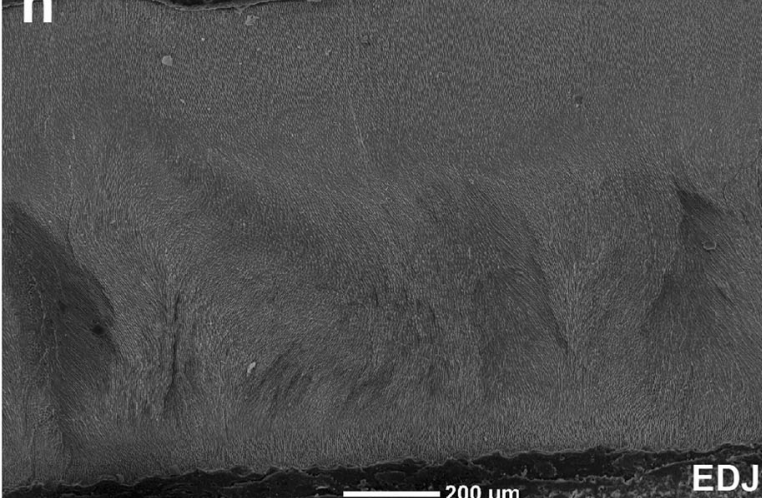

Springer 
Fig. 3 Scanning electron micrographs of Leontiniidae and Toxodontidae. a and b Leontinia (MNHN.F.DES 524), labial side of I1, longitudinal and transverse sections. c and d Adinotherium (MACN A-5367, STIPBKOE3415), labial side of i1, longitudinal and transverse sections, with focus on undulated EDJ. e and f Nesodon (MACN A-11167, STIPBKOE3422), labial side of I1, longitudinal section, (MACN A-11167, STIPB-KOE3421), labial side of I2, transverse section. $\mathbf{g}$ and $\mathbf{h}$ Toxodon (MLP 12-1204, STIPB-KOE3403), labial side of i1, longitudinal section, (MLP P.63, STIPB-KOE3401), labial side of I1, transverse section. EDJ: enamel dentine junction; OES: outer enamel surface. The white arrow indicates the apex of the incisor on longitudinal sections

EDJ in the lower incisors of Adinotherium and Toxodon, while it also forms interrow sheets in the HSB and near the EDJ in upper incisors of Nesodon. The EDJ is undulated (Fig. $3 \mathrm{~d}-\mathrm{h}$ ).

The maximal angle between the IPM and prisms is quite similar between incisors of Adinotherium and Nesodon (about $80-90^{\circ}$, and $85-90^{\circ}$ respectively), while it is slightly slower in Toxodon (about $65-80^{\circ}$ ).

\section{Typotheria}

\section{Early diverging Typotheria}

cf. Oldfieldthomasia: I1, I2 or I3, i1, i2 or i3 (Fig. 4a, b; Table 2).

Cf. Oldfieldthomasia presents enamel on both sides of the upper and lower incisors. In the upper incisors, the enamel is $\sim 110-410 \mu \mathrm{m}$ thick and in the lower incisors between $\sim 190$ $360 \mu \mathrm{m}$. The enamel displays the same microstructure on both upper and lower incisors and on both sides.

The schmelzmuster is one-layered and exclusively represented by radial enamel. Prism diameter measures $6 \mu \mathrm{m}$. Prisms are inclined in the radial enamel of I2/I3 and of the lingual side of I1 compared to both planes, while they are only slightly inclined on the labial side of I1. Prisms are inclined in the radial enamel near the EDJ of i1 and i2/i3. They are less inclined regarding the transverse plane near the OES. The IPM forms closed coats to intermediate along the entire thickness. The maximal angle between the IPM and prisms is about $55-65^{\circ}$.

\section{Interatheriidae}

cf. Notopithecus: undetermined upper incisor, i1 or i2, i2 or i3; Protypotherium: I1, I2, I3, i1, i2, i3; Interatherium: I1, i1, i2. (Fig. 4c-f; Table 2).

Interatheriidae present enamel on both sides of lower incisors but only on the labial side of the upper incisors (except in Interatherium). The enamel is thicker on the transverse section of the upper incisors in Interatherium and Protypotherium (between $\sim 90-320 \mu \mathrm{m})$ than in cf. Notopithecus $(\sim 70 \mu \mathrm{m})$.
On the lower incisors, the enamel is $\sim 180-305 \mu \mathrm{m}$ thick in Notopithecus, $\sim 150-210 \mu \mathrm{m}$ in Protypotherium, and $\sim 90$ $150 \mu \mathrm{m}$ in Interatherium.

The enamel microstructure varies within the family. The enamel shows different microstructures between the upper and lower incisors (except in cf. Notopithecus), but it is similar between the labial and lingual sides (except in Interatherium). Notopithecus present a one-layered schmelzmuster with radial enamel. Prisms are inclined, and their diameter is $\sim 7-8 \mu \mathrm{m}$. The IPM forms closed coats on the entire thickness, but it is slightly anastomosing near the EDJ.

The same microstructure pattern is observed on the lingual side of I1 and on the lower incisors in Interatherium. Prism diameter is $\sim 6 \mu \mathrm{m}$. The labial side of I1 of Interatherium is characterized by a three-layered schmelzmuster represented by IRE and ORE (16\% and 17\%, respectively) and prisms present a slightly wavy pattern in the intermediate layer $(67 \%)$ on the transverse section, which indicates the presence of incipient HSB. The IPM forms closed coats in the entire thickness, but it is also slightly anastomosing near the EDJ.

The upper incisors of Protypotherium are characterized by a three-layered schmelzmuster represented by ORE (14$21 \%$ ), HSBs $(76-86 \%)$, and IRE (5\%). Prism diameter is $\sim 6 \mu \mathrm{m}$. The HSBs are thin $(20-50 \mu \mathrm{m}$ thick) and oblique. The IPM forms closed coats near the OES and interrow sheets near the EDJ, and is intermediate to modified in the HSBs. Lower incisors of Protypotherium are characterized by a onelayered schmelzmuster with HSBs. Prism diameter is $\sim 6 \mu \mathrm{m}$. HSBs are generally oblique and steady, even if they present a low decussation on both sections and are less discernible on some transverse sections. The IPM forms closed coats in the entire thickness, but it is also slightly anastomosing near the EDJ.

If the maximal angle between the IPM and prisms is about $45-55^{\circ}$ in cf. Notopithecus, it is higher and quite similar in Interatherium and Protypotherium (about $60-70^{\circ}$ and $65-75^{\circ}$, respectively).

\section{Hegetotheriidae}

Hegetotherium: I1, i1; Pachyrukhos: I1, i1, i2; Paedotherium: I1, i1, i2; Tremacyllus: I1, i1, i2 (Figs. 4g, h, 5a-d; Table 2).

Hegetotheriidae present enamel on both sides of the upper and lower incisors. In Hegetotheriidae, the enamel is thinner compared to other notoungulates. Indeed, on the transverse section of the upper incisors, the enamel is $\sim 120 \mu \mathrm{m}$ thick in Hegetotherium, $\sim 60-100 \mu \mathrm{m}$ in Pachyrukhos, $\sim 40-100 \mu \mathrm{m}$ in Paedotherium, and $\sim 40-75 \mu \mathrm{m}$ in Tremacyllus. On the lower incisors, the enamel is $\sim 80-160 \mu \mathrm{m}$ thick in Hegetotherium, 70-150 $\mu \mathrm{m}$ in Pachyrukhos, $\sim 70-180 \mu \mathrm{m}$ in Paedotherium, and $\sim 80-150 \mu \mathrm{m}$ in Tremacyllus.

The enamel microstructure is quite similar among hegetotheriids (except regarding the lower incisors of 

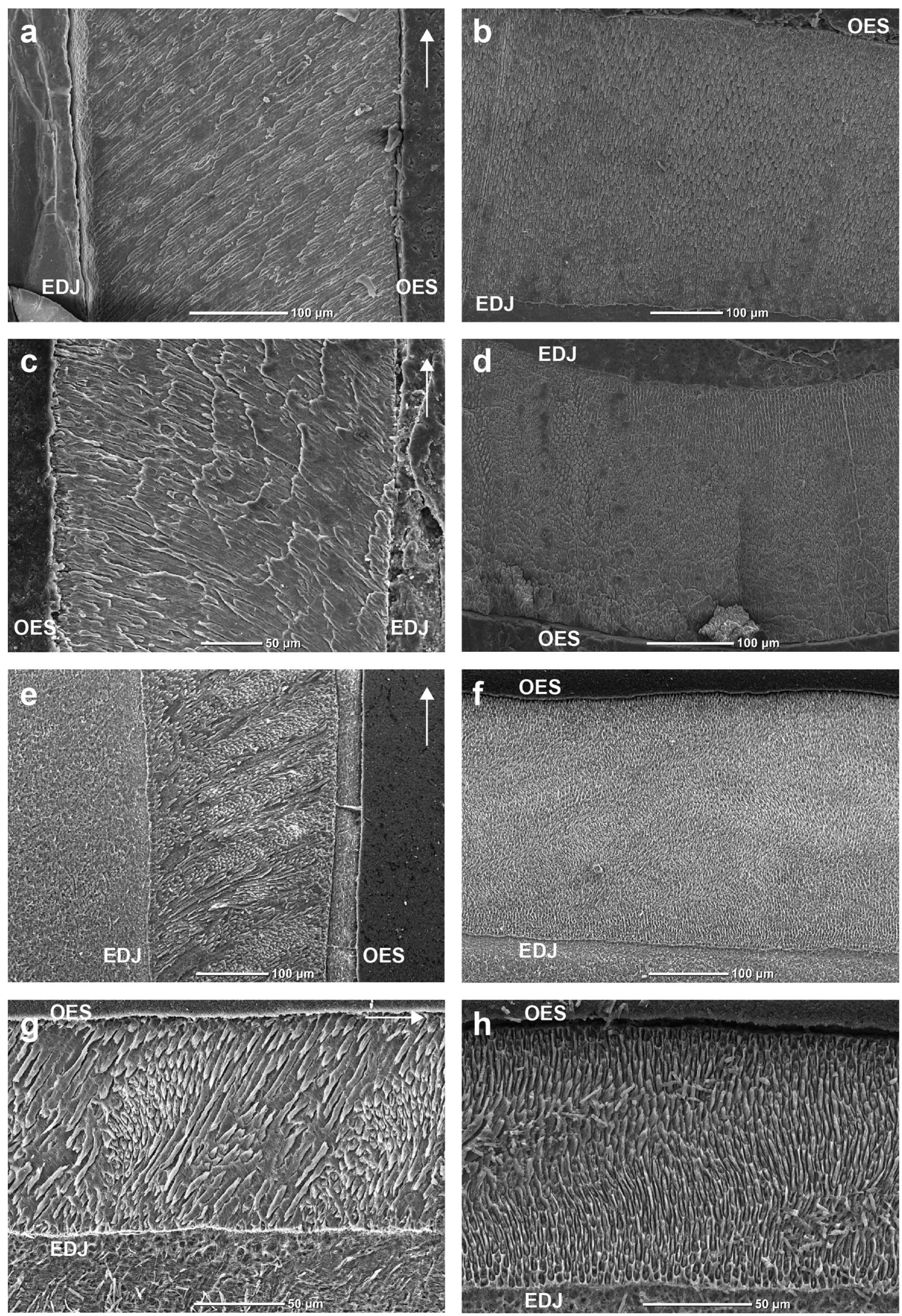
Fig. 4 Scanning electron micrographs of early diverging Typotheria, Interatheriidae and Hegetotheriidae. a and $\mathbf{b}$ cf. Oldfieldthomasia (MNHN.F.CAS 2710), labial side of I1, longitudinal and transverse sections. $\mathbf{c}$ and $\mathbf{d}$ cf. Notopithecus (MNHN.F.CAS 2713), labial side of i1 or i2, longitudinal and transverse sections. e and f Protypotherium (MACN A-9650, STIPB-KOE3407), labial side of I1, longitudinal and transverse sections. $\mathbf{g}$ and $\mathbf{h}$ Hegetotherium (MACN A-9910, STIPBKOE3406), labial side of I1, longitudinal and transverse sections. EDJ: enamel dentine junction; OES: outer enamel surface. The white arrow indicates the apex of the incisor on longitudinal sections

Paedotherium). They have a general pattern characterized by different enamel schmelzmusters between the upper and lower incisors, as well as between the labial and lingual sides (mostly for the upper incisor). Prism diameter is generally $\sim 4-5 \mu \mathrm{m}$, but $6 \mu \mathrm{m}$ was measured for the I1 of Hegetotherium. HSBs are only observed on the labial side of I1 in all hegetotheriids, and on the lingual side of lower incisors in Paedotherium. They are thin $(10-45 \mu \mathrm{m})$ steady and oblique, given they are clearly discernible in longitudinal and transverse sections. The IPM generally forms closed coats, it is sometimes intermediate on the entire thickness especially regarding the labial side of the lower incisors, and interrow sheets are only observed on the labial sides of the lower incisors in Paedotherium.

More generally, the labial side of I1 of all hegetotheriids, and the lingual side of lower incisors of Paedotherium are characterized by a two-layered schmelzmuster with ORE (18-49\%) and HSBs (54-82\%). The lingual side of both I1 and lower incisors, except in Paedotherium, are characterized by a one-layered schmelzmuster represented exclusively by radial enamel. The labial side of the lower incisors is characterized also is represented by radial enamel, but prisms present different orientations near the EDJ compared to the OES.

The maximal angle between the IPM and prisms is quite similar in the incisors of Hegetotherium, Pachyrukhos, and Tremacyllus (about $65-80^{\circ}, 65-90^{\circ}$, and 60-80 $0^{\circ}$, respectively), while it is slightly lower in Paedotherium (about 55-75 ${ }^{\circ}$ ).

\section{Mesotheriidae}

Trachytherus: I1, i2; Plesiotypotherium: I1, i1, i2; Pseudotypotherium: I1; Mesotherium: i1 (Fig. 5e-h; Table 2).

Mesotheriidae present enamel on both sides of the upper and lower incisors, except on the lingual side of I1 in Trachytherus. The investigated mesotheriids also display the same enamel microstructure. On the transverse section of the upper incisors, the enamel is thicker in Trachytherus $(\sim 650 \mu \mathrm{m})$ than in Plesiotypotherium $(\sim 330-350 \mu \mathrm{m})$ and Pseudotypotherium ( $300-380 \mu \mathrm{m})$. On the lower incisors, the enamel is $\sim 330-520 \mu \mathrm{m}$ thick in Trachytherus, 260 $440 \mu \mathrm{m}$ in Plesiotypotherium, and $\sim 270-280 \mu \mathrm{m}$ in Mesotherium. The investigated Mesotheriidae are characterized by a three-layered schmelzmuster represented by IRE and ORE (13-54\% and 8-24\%) and HSBs (27-77\%). Prism diameter is $\sim 6-8 \mu \mathrm{m}$. Prism orientation is different in the central parts of the enamel band compared to the outer parts of the bands. The variation of the thickness of HSBs is high among Mesotheriidae (20-130 $\mu \mathrm{m}$ thick). HSBs are oblique except in Trachytherus and in the lingual side of I1 of Plesiotypotherium and Mesotherium (cf. Lindenau 2005) where they are slightly inclined compared to the transverse plane. HSBs are also discernible on the transverse section, except in Plesiotypotherium on the lingual side of I1, Mesotherium on I1, and Trachytherus, which presents prisms with a slightly wavy pattern in the middle layer. When present, HSB have a steady aspect, except for lower incisors of Trachytherus and Mesotherium. The IPM forms interrow sheets near the EDJ and in HSBs and is variably intermediate regarding the labial sides of lower incisors. We only observed closed coats IPM near the OES.

The maximal angle between the IPM and prisms is about 50-65 in Trachytherus. This angle is higher in Mesotherium (about $80-85^{\circ}$ ), and in Plesiotypotherium and Pseudotypotherium (both about 85-90).

\section{Discussion}

\section{Evolutionary History of Incisor Enamel Microstructure in Notoungulates}

Notoungulates present a wide diversity of incisor shapes and crown heights, which is accompanied by diverse enamel microstructure patterns (Fig. 6, Table 2), as already noticed for molars (Pfretzschner 1992; Maas 1997; Lindenau 2005). This diversity (e.g., presence of HSB, IPM characteristics) is also observed between the different incisor loci in many notoungulates. These differences are especially obvious between upper and lower incisors of the same taxon (Figs. 6 and 8), and far less between adjacent teeth, despite frequent differences in size (see Tables 1 and 2). The family Interatheriidae provides a good example of the spectrum of microstructural evolutionary traits that exists in notoungulates. Great differences of schmelzmusters can indeed be found within the Interatheriidae, which occur over a long time span between the earliest (i.e., Notopithecus) and latest sampled genera (i.e., Interatherium; Fig. 7). Many characters are different between these taxa: the tooth morphology, the distribution of enamel, the number of layers, and the orientation of HSBs. Minor differences are also observed between the Miocene interatheriine taxa Protypotherium and Interatherium, but more important differences are also observed between upper and lower incisors (Fig. 8).

Most of the Eocene notoungulates incisors studied here present only radial enamel (Fig. 7). Cf. Thomashuxleya is the only Eocene taxon presenting a derived schmelzmuster with HSB, also combined with a high angle between the 

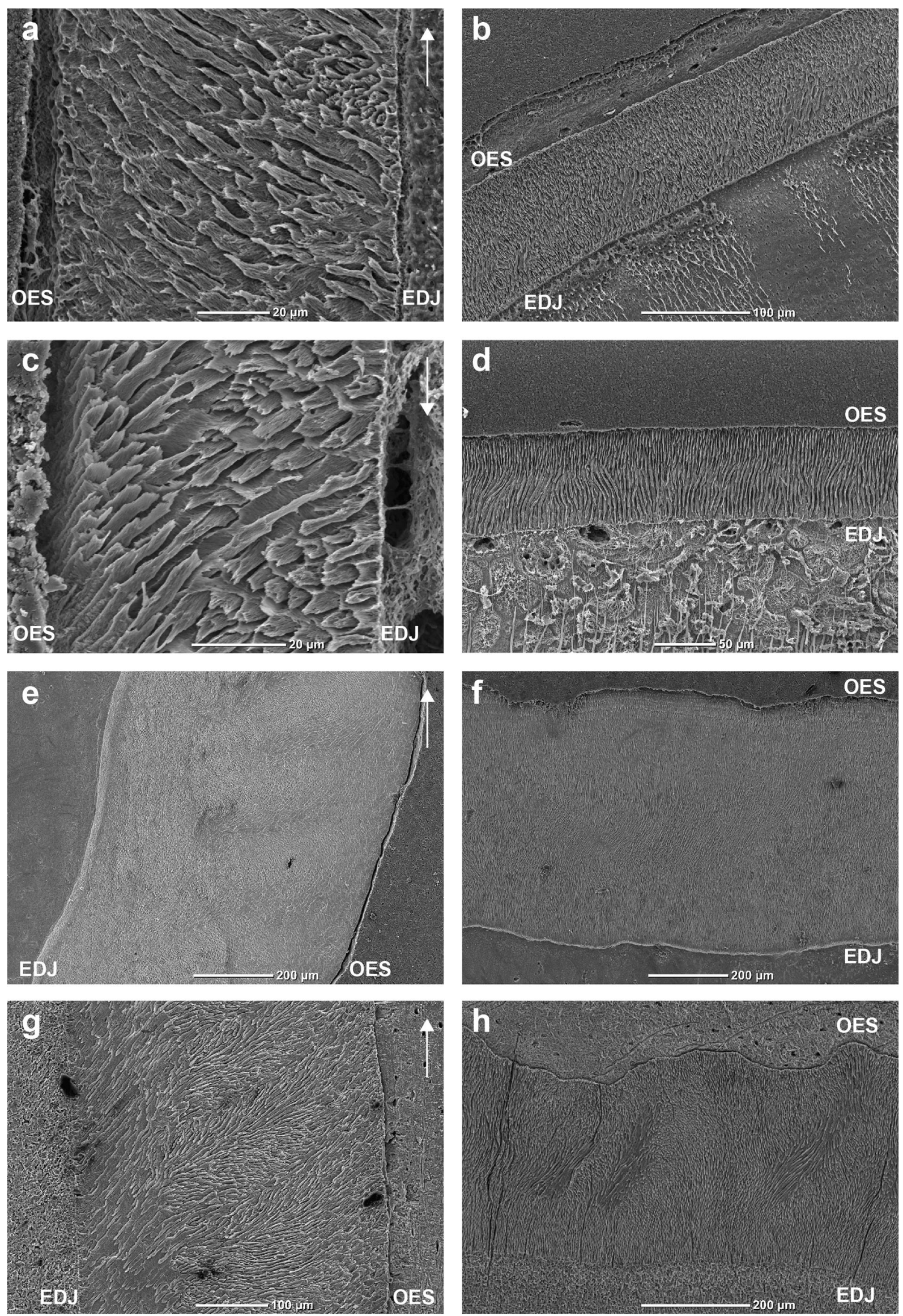
Fig. 5 Scanning electron micrographs of Hegetotheriidae and Mesotheriidae. a and b Pachyrukhos (MLP 73-VII-6-4, STIPBKOE3299), labial side of I1, longitudinal and transverse sections. $\mathbf{c}$ and d Tremacyllus (MLP 76-XII-3-13, STIPB-KOE3291), labial side of I1, longitudinal and transverse sections. e and $\mathbf{f}$ Trachytherus (MNHN.F.SAL 1049), labial side of I1, longitudinal and transverse sections. g and h Pseudotypotherium (MACN 14817, STIPBKOE3413), labial side of I1, longitudinal and transverse sections. EDJ: enamel dentine junction; OES: outer enamel surface. The white arrow indicates the apex of the incisor on longitudinal sections

IPM and prisms (i.e., $80^{\circ}$, Fig. 7). This kind of schmelzmuster involving HSB is observed in all investigated notoungulate families from the Oligocene onwards, even if it does not concern all incisors (Fig. 7). Parsimonious reconstruction suggests that HSB have evolved convergently within Typotheria (i.e., Interatheriidae, Hegetotheriidae, Mesotheriidae), Toxodontia, and Pyrotheria, on lower incisors (Fig. 8). Conversely, HSB is regarded as plesiomorphic for upper incisors when mapped on the tree of sampled genera. This scenario is however questionable given that HSB are widely considered as a derived condition in mammals (e.g., Koenigswald et al. 1987). A greater diversity of sampled Eocene genera might have allowed to obtain this expected evolutionary pattern for notoungulate upper incisors. These results at least clearly suggest that HSBs could be first achieved for upper incisors in comparison to lower ones (e.g., Eurygenium, Interatheriidae, Hegetotheriidae; Figs. 6 and 8). In addition, HSB are more developed in incisors of medium to large notoungulates (e.g., Leontinia, Toxodontidae, Mesotheriidae), where they are present in all investigated loci and incisor sides. All high-crowned taxa investigated in notoungulates presented HSBs on their upper incisors, but not always on their lowers. HSBs evolved in a large number of placental clades (Koenigswald et al. 1987, 2011) and not exclusively in hypsodont or hypselodont taxa, and this is also the case in notoungulates (e.g., the brachydont Thomashuxleya). These widespread structures are recognized as an effective crack-stopping mechanism in enamel (Pfretzschner 1992; Koenigswald et al. 2011). Most importantly, the common occurrence of HSB in notoungulate incisors adds to the growing body of evidence that the clade Euungulata, comprising Perissodactyla, Artiodactyla, and potentially Litopterna and Notoungulata (Welker et al. 2015; Buckley 2015; Westbury et al. 2017), may be characterized by a frequent development of HSB (Stefen 1999; Lindenau 2005; Alloing-Seguier et al. 2014; Tabuce et al. 2017).

Most post-Oligocene notoungulates convergently acquired at least intermediate levels of modified radial enamel (anastomosing IPM) notably near the EDJ, whereas Mesotheriidae were among the only ones to evolve a fully modified radial enamel (IPM forming interrow sheets; Figs. 7 and 8). Surprisingly and conversely to HSB, radial enamel is more often modified in lower than in upper incisors in our sample. More generally, the development of modified enamel is observed in most hypsodont to hypselodont incisors but not in the taxa with brachydont incisors (see interrow sheets on Fig. 6). As noticed in many large ungulates, the development of modified radial enamel might be associated with an increase in crown height (Pfretzschner 1992), and this innovation is assumed as a structural adaptation to radial stresses on highcrowned dentitions (Pfretzschner 1992). Nonetheless, this association does not represent an obligate condition in notoungulates given its absence in high-crowned or evergrowing incisors of Pyrotherium, Interatherium, Hegetotheriidae, and Toxodon (only for upper incisors in the two latter taxa). The angle between the IPM and prisms also tends to increase with most taxa showing low values during the Paleogene, while maximal values (i.e., $90^{\circ}$ ) were reached during the Miocene, in most late-diverging families except interatheriids (Fig. 7).

\section{Phylogenetic Implications of Incisor Enamel Microstructure in Notoungulates}

Our study shows that there is a high number of convergences in the enamel microstructure (e.g., presence of HSB, pattern and orientation of IPM) and crown height of incisors in Notoungulata (Figs. 6 and 8). These convergences are also observed for molars regarding both enamel microstructure and crown height (Maas 1997; Lindenau 2005). The distribution of enamel microstructural features could even make it easier to discriminate early diverging from late diverging notoungulates (i.e., Paleogene versus Neogene taxa) rather than to discriminate between late diverging families (i.e., Toxodontidae, Interatheriidae, Hegeotheriidae, Mesotheriidae). This high homoplasy in the investigated characters could cast doubts on the ability of enamel microstructure traits to help clarify uncertain phylogenetic relationships among notoungulates (Cifelli 1993; Billet 2010; Reguero and Prevosti 2010), as previously noted by Maas (1997) for molars.

Nonetheless, some characters may still constitute interesting synapomorphies of several notoungulates clades. For example, Mesotheriidae represent the only clade having modified radial enamel in all incisors. Hegetotheriidae depart from the rest of notoungulates in showing distinct enamel microstructure patterns on the lingual side and the labial side of incisors, especially on upper incisors. Toxodontidae and Leontiniidae present an unusual pattern involving furcated HSB and strong undulation of the EDJ. Consequently, the different levels of complexity of incisor enamel (Koenigswald and Clemens 1992; Koenigswald et al. 1993), in connection with results from molar enamel (Pfretzschner 1992; Lindenau 2005), should be carefully considered when searching for phylogenetically informative characters in 


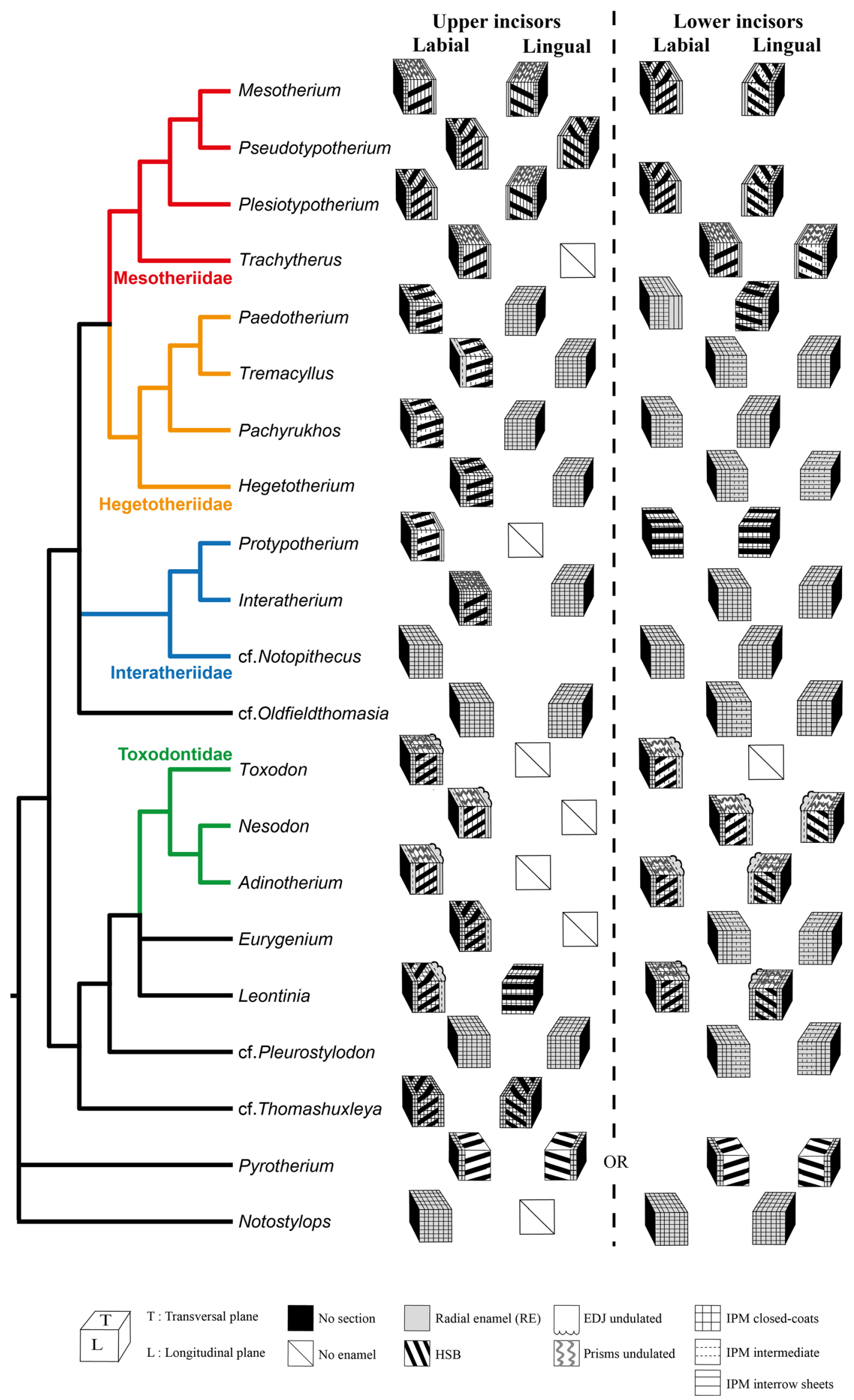


Fig. 6 Incisor enamel microstructure diversity within notoungulates plotted on a phylogenetic tree, combining results from Billet (2011) and Shockey et al. (2016)

notoungulates. Such phylogenetic information includes variations observed within the schmelzmuster, between labial and lingual sides, and between incisor positions (especially upper and lower incisor, Figs. 6 and 8), depending on their level of integration (i.e., trend to co-vary).

\section{Comparisons with Closest Extant and Extinct Relatives}

Notoungulata, together with Litopterna (and possibly Astrapotheria; Billet 2010), were reported to be more closely related to Perissodactyla than to any other extant taxon of placentals (Welker et al. 2015; Buckley 2015; Westbury et al. 2017). Among perissodactyls, there are three different configurations of HSB observed for incisors (Koenigswald et al. 2011): transverse HSB (the HSB are parallel to the occlusal surface and the base of enamel crown), vertical HSB (the HSB are perpendicular to the occlusal surface and the base of enamel crown), and compound HSB (transverse HSB in an inner layer and vertical HSB in an outer layer). Unlike perissodactyls, notoungulates having HSB only showing the transverse to oblique configurations. Koenigswald et al. (2011) stated that the transverse HSB is the ancestral configuration when HSB appeared in perissodactyls, and this pattern is still present in incisors of Equidae, as observed in notoungulates. Unfortunately, no data on incisor enamel microstructure are available for Litopterna to date, but a few data on Astrapotheria incisors are presented in Lindenau's thesis (Lindenau 2005). The investigated lower incisors of Astrapotheria present a different condition in having vertical HSB (Lindenau 2005), a configuration defined as derived in perissodactyls, and only found in molars and incisors of some Rhinocerotoidea (Koenigswald et al. 2011).

The transverse HSBs have the optimal configuration to withstand the tensile stresses and reduce crack propagation in being parallel to the occlusal surface, but they are less resistant to abrasion (Pfretzschner 1988; Koenigswald et al. 2011). Transverse HSBs are observed in equids (for both Hypsodont $\int$ Hypselodont $\square$ HSB Int/IS: IPM Intermediate/Interrow sheet $0^{\circ}:$ Max angle IPM vs prisms

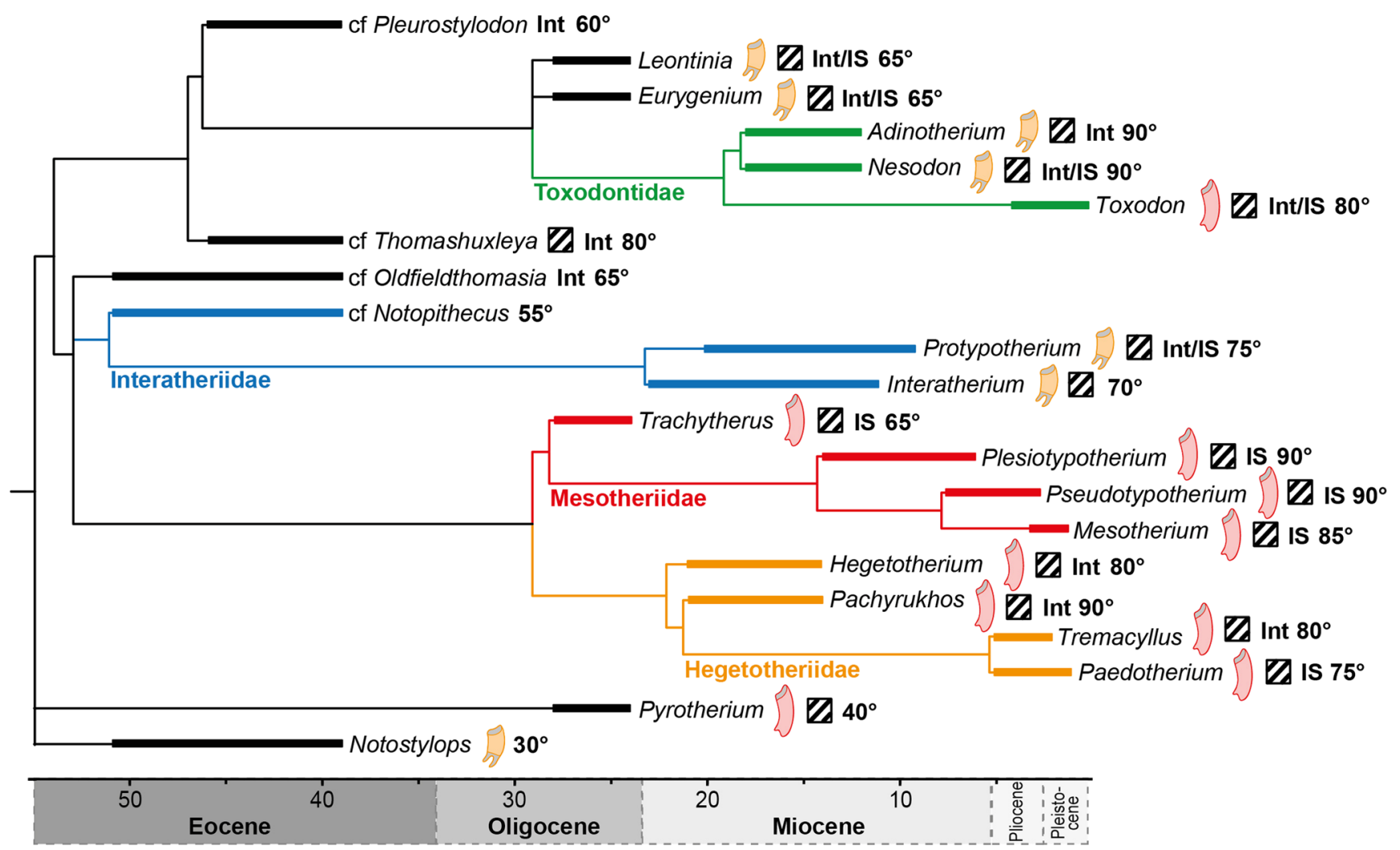

Fig. 7 Phylogenetic relationships and stratigraphic range of notoungulate taxa (from Reguero and Prevosti 2010; Billet 2011; Shockey et al. 2016), with associated incisor crown heights and main modifications of the enamel microstructure concerning development of HSB and arrangement of IPM compared to prisms (absence of each pictogram means brachydonty, radial enamel only, and closed coat of IPM) 


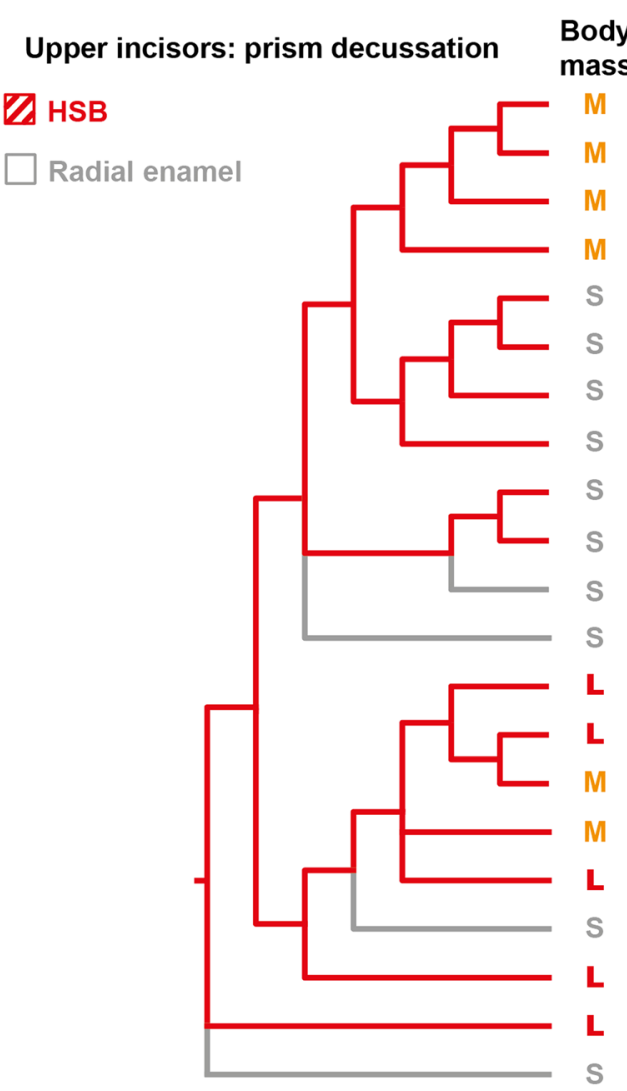

y ss Mesotherium

Pseudotypotherium

Plesiotypotherium

Trachytherus

Paedotherium

Tremacyllus

Pachyrukhos

Hegetotherium

Protypotherium

Interatherium

cf. Notopithecus

cf. Oldfieldthomasia

Toxodon

Nesodon

Adinotherium

Eurygenium

Leontinia

cf. Pleurostylodon

cf. Thomashuxleya

Pyrotherium

Notostylops
Crown height

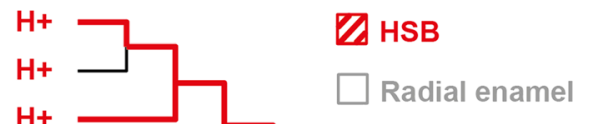

Upper incisors: IPM characteristics

IS: interrow sheet

Int: intermediate

CC: closed coat

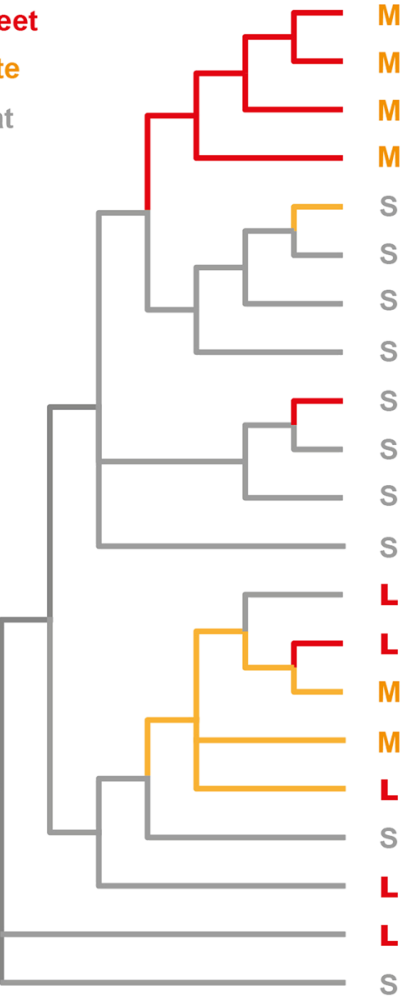

\section{Mesotherium}

Pseudotypotherium

Plesiotypotherium

Trachytherus

Paedotherium

Tremacyllus

Pachyrukhos

Hegetotherium

Protypotherium

Interatherium

cf. Notopithecus

cf. Oldfieldthomasia

Toxodon

Nesodon

Adinotherium

Eurygenium

Leontinia

cf. Pleurostylodon

cf. Thomashuxleya

Pyrotherium

Notostylops
$\mathrm{H}+$
$\mathrm{H}+$
$\mathrm{H}+$
$\mathrm{H}+$
$\mathrm{H}+$
$\mathrm{H}+$
$\mathrm{H}$
$\mathrm{H}$
$\mathrm{B}$
$\mathrm{B}$
$\mathrm{H}+$
$\mathrm{H}$
$\mathrm{H}$
$\mathrm{H}$
$\mathrm{H}$
$\mathrm{B}$
$\mathrm{B}$
$\mathrm{B}$

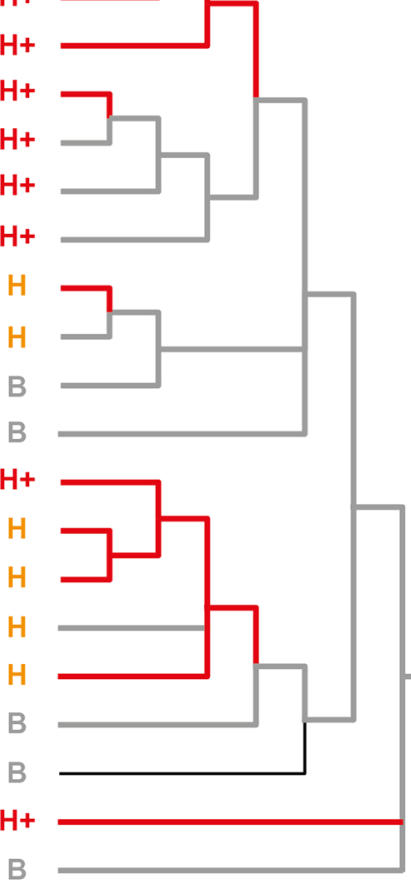

Lower incisors: IPM characteristics

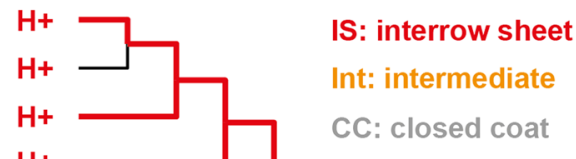

Estimated body mass

Crown height
S: small $<10 \mathrm{~kg}$

B: brachydonty
$10 \mathrm{~kg}<\mathrm{M}:$ moderate $<100 \mathrm{~kg}$

$\mathrm{H}$ : hypsodonty
$100 \mathrm{~kg}$ < L: large

$\mathrm{H+}$ : hypselodonty 
Fig. 8 Comparison of the distributions of incisor crown height states, body mass (Croft 2000; Reguero et al. 2010; Gomes Rodrigues et al. 2017), and parsimonious reconstruction of evolution of prism decussation and IPM characteristics on the composite tree of notoungulates (Billet 2011; Shockey et al. 2016). Black branches represent an absence of data for the respective character

incisors and molars; Pfretzschner 1993; Koenigswald et al. 2011), in which acquisition of high-crown dentitions combined with modified radial enamel probably allowed reduction of the effect of intense abrasion (Pfretzschner 1994). Interestingly, this combined acquisition of high-crowned incisors and modified radial enamel is convergently observed in many notoungulates (for both incisors and molars, Lindenau 2005). Moreover, this combination associated with a reorientation of prisms (i.e., oblique HSBs, meaning that they tend to be vertical) as observed in many incisors of notoungulates, could represent an improved resistance to abrasion. In fact, when HSBs are vertical, they present an optimum prism orientation perpendicular to the occlusal surface, which is considered to be an advantage for reducing the effect of abrasion (Koenigswald et al. 2011).

While aridity and volcanism increased in Patagonia and probably in other parts of South America during the midCenozoic, South American ungulates, and especially those eating close to the ground and/or with a strong chewing effort, probably ingested high quantities of exogenous abrasive particles (Billet et al. 2009; Strömberg et al. 2013; Madden 2015; Gomes Rodrigues et al. 2017; see also Janis 1988, 1995; Mainland 2003). In that context, various dental configurations with different strategies against abrasion emerged among these ungulates: (1) notoungulates with transverse to oblique HSB and very high-crowned incisors and molars, as partly observed in equids, (2) and astrapotheres with vertical HSB with lower-crowned incisors and molars, as observed in rhinocerotoids (at least for molars).

\section{Comparison with Extant Analogues and Morpho-Functional Hypotheses}

Certain enamel structural characteristics may have evolved in response to high forces applied during the mastication of specific food items or exogenous particles. For example, Shimizu and Macho (2007) showed that the development of an undulated EDJ in some extant primates evolved in response to high masticatory forces. However, these authors also suggested that the equivocal relationship between undulation and presumed bite force could in fact represent exaptations within primates (see Shimizu and Macho 2007). In some toxodontian notoungulates, the EDJ undulates and is accompanied by prolonged growth of incisors and a three-layered schmelzmuster (IRE-HSB-ORE; Fig. 6). However, most notoungulates (Pyrotherium, Eurygenium, Protypotherium,
Interatherium, Mesotheriidae, and Hegetotheriidae) present a prolonged to continuous growth of incisors and a threelayered schmelzmuster without the undulation of the EDJ. In our sample, the undulated EDJ was found only within the families Leontiniidae and Toxodontidae. This may represent a single evolutionary event given the possible close relationship between these taxa (Billet 2011) and this undulation may - as in primates - be an exceptional feature. The functional importance of this undulation is difficult to evaluate and it could also be investigated whether the development of this structure could be linked to large body masses in notoungulates, such as found in Leontiniidae and Toxodontidae (body mass estimates by Croft 2000; Reguero et al. 2010; Gomes Rodrigues et al. 2017; Leontiniidae: 50$210 \mathrm{~kg}$ and Toxodontidae: $10 \mathrm{~kg}-1650 \mathrm{~kg}$ ).

The development of continuous growth in notoungulate incisors, especially in late diverging families, is a major morphological innovation, which was often accompanied by changes in the enamel microstructure (HSBs, modified radial enamel). It can also be accompanied by a reduction of the number of incisors, especially for uppers (e.g., Hegetotheriidae, Mesotheriidae) or the loss of enamel on the lingual side of upper incisors (e.g., Trachytherus, Toxodon). The reduction in the number of incisors toward one prominent pair of upper incisors is a trend also observed in extant mammals that present hypselodont incisors (e.g., rodents, rabbits, hyraxes). This pattern can confer a higher bite force at the incisor level as demonstrated for rodents (Druzinsky 2010; Cox et al. 2012), and this may have been the case for rodent-like notoungulates (Hegetotheriidae, Mesotheriidae). However, the complexity of incisor enamel microstructure observed in rodents (Wahlert and Koenigswald 1985; Martin 1997; Kalthoff 2000, 2006; Koenigswald 2004; Koenigswald and Kalthoff 2007; Gomes Rodrigues et al. 2013; Gomes Rodrigues 2015) is much higher than that observed in notoungulates. If we except modifications associated with crown height increase (i.e., modified radial enamel), the loss of lingual enamel observed in rodents is only reported in a few notoungulates (Notostylops, Toxodontidae, Protypotherium, Trachytherus), and this does not involve rodent-like species (i.e., Hegetotheriidae, Mesotheriinae). Consequently, these important microstructural differences hamper comparisons of notoungulate incisors with those of rodents from a functional viewpoint.

The loss of lingual enamel could be associated with the category "enamel-band hypsodonty" (Koenigswald 2011), which comprises hypsodont teeth that have enamel only on one or two sides, while the dentine surface covers more than one third of the circumference of the tooth. Stiff enamel is less favored in incisors that need to be more elastic to prevent breakage, as observed in rodents and a few primates (Druzinsky et al. 2012; Kupczik and Chattah 2014). The selection of the loss of lingual enamel is 
associated with balanced wear (Koenigswald 2011), and is in turn probably correlated to the specific functional roles of incisors (e.g., gathering food, foraging, digging, fighting). It is also known that the loss of enamel on one side of incisors has evolved independently in various mammalians lineages, and this character is sporadically present in notoungulates. This raises questions on why some species kept enamel on both sides or on only one side.

As mentioned above, incisors may have a large variety of functional roles. Previous investigations have shown that some behavior for food intake (e.g., cutting, shearing, gnawing) or digging can shape the morphological characteristics of incisors in mammals (the incisors are protruding anteriorly, they have long "roots" and are thick; Becerra et al. 2012). In notoungulates, while fossorial habits have been proposed for rodent-like Hegetotheriidae (Cassini et al. 2012) and Mesotheriidae (Shockey et al. 2007), it is not established whether or not their incisors could have served as digging tools. Both closely related families present derived morphologies of their incisor enamel microstructure, with the presence of HSB and inner modified enamel. These features are also convergently found within non-digging notoungulates such as toxodontids. Thus, no clear link exists between a putative fossorial lifestyle and such specialization of the enamel microstructure within our sample.

\section{Conclusions}

This study shows that notoungulates exhibit diverse enamel microstructural patterns for their incisors, with several features being convergently acquired throughout their evolutionary history. More precisely, the following patterns along with the incisor crown height (regardless of its position) could be highlighted: most brachydont taxa only present radial enamel, which generally correspond to early diverging taxa; most hypsodont to hypselodont taxa present inner and outer radial enamel with intermediate IPM or completely modified radial enamel and transverse to oblique HSBs; incisors with modified radial enamel are found only in post-Eocene taxa. The latter characters often represent convergent acquisitions among late-diverging families, and may have evolved in response to various biomechanical stresses, such as increased abrasion.

The diversity of enamel patterns observed in notoungulate incisors at different levels of microstructural complexity will be of interest for phylogenetic reconstructions and characterization of early to late-diverging taxa, including also cheek teeth. Further analyses are necessary to comment on the potential roles that other factors such as development, body size, and masticatory function may have on enamel microstructure evolution in mammals and in notoungulates in particular.
Acknowledgements We acknowledge the curators A. Kramarz (MACN, Buenos Aires) and M. Reguero (MLP, La Plata) who allowed us to access the paleontological collections of notoungulates and to collect dental samples. We warmly thank W. von Koenigswald (University of Bonn) for giving access to the collection of dental samples from the Steinmann Institute. We also thanks S. Morel, R. Vacant, L. Caze, and P. Loubry (CR2P, MNHN, Paris) for technical help concerning sample preparation, and concerning the use of the SEM. DCK acknowledges the Deutsche Forschungsgemeinschaft (DFG, Bonn, Germany) for various grants to study mammalian enamel microstructure. AF and HGR benefited from LabEx BCDiv grants and this work was also supported by this LabEx (Laboratoire d'Excellence Biological and Cultural Diversities, http:// labex-bcdiv.mnhn.fr/). We also thank D. Croft and the anonymous reviewer for constructive comments on an earlier version of the paper.

Author Contributions DCK, GB, and HGR designed the study, supervised the project and selected the dental specimens. AF, DCK, and HGR prepared the dental samples. AF took the pictures and collected the data. $\mathrm{AF}$ and HGR analyzed the data, prepared the figures, and wrote the manuscript. All authors reviewed, improved, and approved the manuscript.

Data Availability The datasets generated and analyzed during the current study are available from the corresponding author on reasonable request.

Open Access This article is distributed under the terms of the Creative Commons Attribution 4.0 International License (http:// creativecommons.org/licenses/by/4.0/), which permits unrestricted use, distribution, and reproduction in any medium, provided you give appropriate credit to the original author(s) and the source, provide a link to the Creative Commons license, and indicate if changes were made.

\section{References}

Agnarsson I, Miller JA (2008) Is ACCTRAN better than DELTRAN? Cladistics 24:1032-1038

Alloing-Seguier L, Lihoreau F, Boisserie JR, Charruault AL, Orliac M, Tabuce R (2014) Enamel microstructure evolution in anthracotheres (Mammalia, Certatiodactyla) and new insights on hippopotamoid phylogeny. Zool J Lin Soc 171:668-695

Becerra F, Vassallo AI, Echeverria AI, Casinos A (2012) Scaling and adaptations of incisors and cheek teeth in caviomorph rodents (Rodentia, Hystricognathi). J Morphol 273:1150-1162

Billet G (2010) New observations on the skull of Pyrotherium (Pyrotheria, Mammalia) and new phylogenetic hypotheses on South American ungulates. J Mammal Evol 17:21-59

Billet G (2011) Phylogeny of the Notoungulata (Mammalia) based on cranial and dental characters. J Syst Palaeontol 9:481-497

Billet G, Blondel C, Muizon C de (2009) Dental microwear analysis of notoungulates (Mammalia) from Salla (late Oligocene, Bolivia) and discussion on their precocious hypsodonty. Palaeogeogr Palaeoclimatol Palaeoecol 274:114-124

Bond M, Cerdeño E, López GM (1995) Los ungulados nativos de América del Sur. In: Alberdi MT, Leone G, Tonni EP (eds) Evolución Biológica y Climática de la Región Pampeana Durante los Últimos Cinco Millones de Años. Un Ensayo de Correlación con el Mediterráeno Occidental. Monografías del Museo Nacional de Ciencias Naturales, Consejo Superior de Investigaciones Científicas, Madrid, pp 259-292

Buckley M (2015) Ancient collagen reveals evolutionary history of the endemic South American ‘ungulates'. Proc R Soc B 282:20142671 
Cassini GH, Cerdeño E, Villafane AL, Munoz NA (2012) Paleobiology of Santacrucian native ungulates (Meridioungulata: Astrapotheria, Litopterna and Notoungulata). In: Vizcaíno SF, Kay RF, Bargo MS (eds) Early Miocene Paleobiology in Patagonia: High-Latitude Paleocommunities of the Santa Cruz Formation. Cambridge University Press, Cambridge, pp 243-278

Cassini GH, Vizcaíno SF (2012) An approach to the biomechanics of the masticatory apparatus of early Miocene (Santacrucian age) South American ungulates (Astrapotheria, Litopterna, and Notoungulata): moment arm estimation based on 3D landmarks. J Mammal Evol 19:9-25

Cifelli RL (1985) South American ungulate evolution and extinction. In: Stehli FG, Webb SD (eds) The Great American Biotic Interchange. Plenum Press, New York, pp 249-266

Cifelli RL (1993) The phylogeny of the native South American ungulates. In: Szalay FS, Novacek MJ, McKenna MC (eds) Mammal Phylogeny: Placentals. Springer Verlag, New York, pp 195-216

Clemens WA (1997) Characterization of enamel microstructure terminology and applications in systematic analyses. In: Koenigswald W von, Sander PM (eds) Tooth Enamel Microstructure. Balkema, Rotterdam, pp 85-112

Cox PG, Rayfield EJ, Fagan MJ, Herrel A, Pataky TC, Jeffery N (2012) Functional evolution of the feeding system in rodents. PLoS One 7: e36299

Croft DA (2000) Archaeohyracidae (Mammalia: Notoungulata) from the Tinguiririca Fauna, Central Chile, and the Evolution and Paleoecology of South American Mammalian Herbivores. PhD Dissertation, The University of Chicago, Chicago

Croft DA (2001) Cenozoic environmental change in South America as indicated by mammalian body size distributions (cenograms). Diversity and Distributions 7:271-287

Croft DA (2016) Horned Armadillos and Rafting Monkeys: The Fascinating Fossil Mammals of South America. Indiana University Press, Bloomington, $320 \mathrm{pp}$

Croft DA, Flynn JJ, Wyss AR (2008) The Tinguiririca Fauna of Chile and the early stages of "modernization" of South American mammal faunas. Arquivos do Museu Nacional, Rio de Janeiro 66:191-211

Croft DA, Weinstein D (2008) The first application of the mesowear method to endemic South American ungulates (Notoungulata). Palaeogeogr Palaeoclimatol Palaeoecol 269:103-114

Druzinsky RE (2010) Functional anatomy of incisal biting in Aplodontia rufa and sciuromorph rodents. Part 2: Sciuromorphy is efficacious for production of force at the incisors. Cells Tissues Organs 192:50 63

Druzinsky RE, Naveh G, Weiner S, Brumfeld V, Klein OD, Charles C (2012) Mechanical properties of incisors in rodents. The FASEB Journal 26S

Dunn RE, Strömberg CAE, Madden RH, Kohn MJ, Carlini AA (2015) Linked canopy, climate, and faunal change in the Cenozoic of Patagonia. Science 347:258-261

Flynn JJ, Wyss AR (1998) Recent advances in South American mammalian paleontology. Trends Ecol Evol 13:449-455

Giannini NP, García-López DA (2013) Ecomorphology of mammalian fossil lineages: identifying morphotypes in a case study of endemic South American ungulates. J Mammal Evol 21:195-212

Gomes Rodrigues H (2015) The great disparity of dental structures and dynamics in rodents: new insights into their ecological diversity. In: Cox PG, Hautier L (eds) Evolution of the Rodents: Advances in Phylogeny, Functional Morphology and Development. Cambridge University Press, Cambridge, pp 424-447

Gomes Rodrigues H, Herrel A, Billet G (2017) Ontogenetic and life history trait changes associated with convergent ecological specializations in extinct ungulate mammals. Proc Natl Acad Sci USA 114: 1069-1074

Gomes Rodrigues H, Marivaux L, Vianey-Liaud M (2013) On the status of early Eucricetodontinae (Muroidea, Rodentia) with a special focus on the Atavocricetodon vs Eucricetodon issue: morphometrical and microstructural aspects. Spanish J Palaeontol 28:17-28

Jacobs BF, Kingston JD, Jacobs LL (1999) The origin of grass-dominated ecosystems. Ann Mo Bot Gard 86:590-643

Janis CM (1988) An estimation of tooth volume and hypsodonty indices in ungulates mammals, and the correlation of these factors with dietary preferences. In: Russell DE, Santoro JP, Sigogneau-Russell D (eds) Teeth Revisited. Mém Mus natl Hist nat (C) 53:367-387

Janis CM (1995) Correlations between craniodental morphology and feeding behavior in ungulates: reciprocal illumination between living and fossil taxa. In: Thomason JJ (ed) Functional Morphology in Vertebrate Paleontology. Cambridge University Press, Cambridge, pp 76-98

Kalthoff DC (2000) Die Schmelzmikrostruktur in den Incisiven der hamsterartigen Nagetiere und anderer Myomorpha (Rodentia, Mammalia). Palaeontogr Abt A 259:1-193

Kalthoff DC (2006) Incisor enamel microstructure and its implications to the systematics of Eurasian Oligocene and lower Miocene hamsters. Palaeontogr Abt A 277:67-80

Koenigswald W von (2004) Enamel microstructure of rodent molars, classification, and parallelisms, with a note on the systematic affiliation of the enigmatic Eocene rodent Protoptychus. J Mammal Evol $11: 127-142$

Koenigswald W von (2011) Diversity of hypsodont teeth in mammalian dentitions - construction and classification. Palaeontogr Abt A 294: 63-94

Koenigswald W von, Clemens WA (1992) Levels of complexity in the microstructure of mammalian enamel and their application in studies of systematics. Scanning Microscopy 6:195-218

Koenigswald W von, Holbrook LT, Rose KD (2011) Diversity and evolution of Hunter-Schreger band configuration in tooth enamel of perissodactyl mammals. Acta Palaeontol Pol 56:11-32

Koenigswald W von, Kalthoff DC (2007) The enamel microstructure of molars and incisors of Paleogene and early Neogene rodents from Mongolia. Ann Nat Hist Mus Wien 108 A:291-312

Koenigswald W von, Martin T, Billet G (2015) Enamel microstructure and mastication in Pyrotherium romeroi (Pyrotheria, Mammalia). Paläontol Z 89:593-609

Koenigswald W von, Martin T, Pfretzschner HU (1993) Phylogenetic interpretation of enamel structures in mammalian teeth: possibilities and problems. In: Szalay FS, Novacek MJ, McKenna MC (eds) Mammal Phylogeny: Placentals. Springer Verlag, New York, pp 303-314

Koenigswald W von, Rensberger JM, Pfretzschner HU (1987) Changes in the tooth enamel of early Paleocene mammals allowing increased diet diversity. Nature 328:150-152

Koenigswald W von, Sander PM (1997) Glossary of terms used for enamel microstructures. In: Koenigswald W von, Sander PM (eds) Tooth Enamel Microstructure. Balkema, Rotterdam, pp 267-279

Kohn MJ, Strömberg CAE, Madden RH, Dunn RE, Evans S, Alma P, Carlini AA (2015) Quasi-static Eocene-Oligocene climate in Patagonia promotes slow faunal evolution and mid-Cenozoic global cooling. Palaeogeogr Palaeoclimatol Palaeoecol 435:24-37

Korvenkontio VA (1934) Mikroskopische Untersuchungen an Nagerincisiven unter Hinweis auf die Schmelzstruktur der Backenzähne. Ann Zool Fenn 2:1-274

Kramarz AG, Bond M, Rougier GW (2017) Re-description of the auditory region of the putative basal astrapothere (Mammalia) Eoastrapostylops riolorense Soria and Powell, 1981. Systematic and phylogenetic considerations. Ann Carnegie Museum 84(2): 95-164

Kupczik K, Chattah NLT (2014) The adaptative significance of enamel loss in the mandibular incisors of cercopithecine primates (Mammalia: Cercopithecidae): a finite element modelling study. PLoS One 9:1-8 
Lindenau C (2005) Zahnschmelzmikrostrukturen südamerikanischer Huftiere. Dissertation, University of Bonn, Bonn

Maas CM (1997) Enamel microstructure in notoungulates. In: Kay RF, Madden RH, Cifelli RL, Flynn JJ (eds) Vertebrate Paleontology in the Neotropics: The Miocene Fauna of La Venta, Colombia. Smithonian Institution Press, Washington, pp 319-334

MacFadden BJ (2000) Cenozoic mammalian herbivores from the Americas: reconstructing ancient diets and terrestrial communities. Annu Rev Ecol Syst 31:33-59

MacFadden BJ, Wang Y, Cerling TE, Anaya F (1994) South American fossil mammals and carbon isotopes: a 25 million-year sequence from the Bolivian Andes. Palaeogeogr Palaeoclimatol Palaeoecol 107:257-268

Madden RH (2015) Hypsodonty in Mammals - Evolution, Geomorphology, and the Role of Earth Surface Processes. Cambridge University Press, Cambridge

Maddison WP, Maddison DR (2015) Mesquite: a modular system for evolutionary analysis, Version 3.04. Available at http:// mesquiteproject.org

Mainland I (2003) Dental microwear in grazing and browsing Gotland sheep (Ovis aries) and its implications for dietary reconstruction. $\mathrm{J}$ Archaeol Sci 30:1513-1527

Martin T (1997) Incisor enamel microstructure and systematics in rodents. In: Koenigswald W von, Sander PM (eds) Tooth Enamel Microstructure. Balkema, Rotterdam, pp 163-175

Muizon C de, Billet G, Argot C, Ladevèze S, Goussard F (2015) Alcidedorbignya inopinata, a basal pantodont (Placentalia, Mammalia) from the early Palaeocene of Bolivia: anatomy, phylogeny and palaeobiology. Geodiversitas 37:397-634

Nasif NL, Musalem S, Cerdeño E (2000) A new toxodont from the late Miocene of Catamarca, Argentina, and a phylogenetic analysis of the Toxodontidae. J Vertebr Paleontol 20:591-600

Ortiz-Jaureguizar E, Cladera GA (2006) Paleoenvironmental evolution of southern America during the Cenozoic. J Arid Environm 66:498532

Pascual R, Odreman Rivas OE (1971) Evolución de las comunidades de los vertebrados del Terciario argentino; los aspectos paleozoogeográficos y paleoclimáticos relacionados. Ameghiniana 8:372-412

Pascual R, Ortiz-Jaureguizar E (1990) Evolving climates and mammal faunas in Cenozoic South America. J Hum Evol 19:23-60

Pfretzschner HU (1988) Structural reinforcement and crack propagation in enamel. Mem Mus natl Hist Nat Paris ser C 53:133-143

Pfretzschner HU (1992) Enamel microstructure and hypsodonty in large mammals. In: Smith P, Tschernov E (eds) Structure, Function, and Evolution of Teeth. Freund Publishing House, London/Tel Aviv, pp $147-162$

Pfretzschner HU (1993) Enamel microstructure in the phylogeny of the Equidae. J Vertebr Paleontol 13:342-349

Pfretzschner HU (1994) Biomechanik der Schmelzmikrostruktur in den Backenzähnen von Grosssäugern. Palaeontogr Abt A 234:1-88

Reguero MA, Candela AM, Cassini GH (2010) Hypsodonty and body size in rodent-like notoungulates. In: Madden RH, Carlini AA, Vucetich MG, Kay RF (eds) The Paleontology of Gran Barranca: Evolution and Environmental Change through the Middle Cenozoic of Patagonia. Cambridge University Press, Cambridge, pp 358-367

Reguero MA, Prevosti FJ (2010) Rodent-like notoungulates (Typotheria) from Gran Barranca, Chubut Province, Argentina: phylogeny and systematics. In: Madden RH, Carlini AA, Vucetich MG, Kay RF (eds) The Paleontology of Gran Barranca: Evolution and Environmental Change through the Middle Cenozoic of Patagonia. Cambridge University Press, Cambridge, pp 148-165

Renvoisé E, Michon F (2014) An evo-devo perspective on ever-growing teeth in mammals and dental stem cell maintenance. Front Physiol 5: 324

Scott WB (1932) Mammalia of the Santa Cruz Beds. Volume VII, Paleontology. Part III. Nature and origin of the Santa Cruz Fauna with additional notes on the Entelonychia and Astrapotheria. In: Scott WB (ed) Reports of the Princeton University Expeditions to Patagonia, 1896-1899. Princeton University, E. Schweizerbart'sche Verlagshandlung (E. Nägele), Stuttgart, pp 157-192

Scott WB (1937) A History of Land Mammals in the Western Hemisphere, second edn. MacMillan Co., New York

Shimizu D, Macho GA (2007) Functional significance of the microstructural detail of the primate dentino-enamel junction: a possible example of exaptation. J Hum Evol 52:103-111

Shockey BJ, Billet G, Salas-Gismondi R (2016) A new species of Trachytherus (Notoungulata: Mesotheriidae) from the late Oligocene (Deseadan) of southern Peru and the middle latitude diversification of early diverging mesotheriids. Zootaxa 4111:565583

Shockey BJ, Croft DA, Anaya F (2007) Analysis of function in the absence of extant functional homologues: a case study of mesotheriid notoungulates. Paleobiology 33:227-247

Simpson GG (1980) Splendid Isolation: the Curious History of South American Mammals. Yale University Press, New Haven

Stebbins GL (1981) Coevolution of grasses and herbivores. Ann Mo Bot Gard 68:75-86

Stefen C (1999) Evolution of enamel microstructure of archaic ungulates ('Condylarthra') and comments on some other early Tertiary mammals. Paleobios 19:15-36

Strömberg CAE, Dunn RE, Madden RH, Kohn MJ, Carlini AA (2013) Decoupling the spread of grasslands from the evolution of grazertype herbivores in South America. Nat Commun 4:1478

Tabuce R, Seiffert ER, Gheerbrant E, Alloing-Séguier L, Koenigswald W von (2017) Tooth enamel microstructure of living and extinct hyracoids reveals unique enamel type among mammals. J Mammal Evol 24:91-110

Townsend KE, Croft DA (2008) Diets of notoungulates from the Santa Cruz Formation, Argentina: new evidence from enamel microwear. J Vertebr Paleontol 28:217-230

Wahlert JH, Koenigswald W von (1985) Specialized enamel in incisors of eomyid rodents. Am Mus Novitates 2832:1-12

Welker F, Collins MJ, Thomas JA, Wadsley M, Brace SEA (2015) Ancient proteins resolve the evolutionary history of Darwin's South American ungulates. Nature 522:81-84

Westbury M, Baleka S, Barlow A, Hartmann S, Paijmans JLA, Kramarz A, Forasiepi AM, Bond M, Gelfo JN, Reguero MA, López Mendoza P, Taglioretti M, Scaglia F, Rinderknecht A, Jones W, Aguilar JL, Billet G, Muizon C de, MacPhee RDE, Hofreiter M (2017) A mitogenomic timetree for Darwin's "transitional" South American mammal, Macrauchenia patachonica. Nat Comm 8:15951. DOI: https://doi.org/10. 1038/ncomms 15951

Woodburne MO, Goin FJ, Bond M, Carlini AA, Gelfo JN, López GM, Iglesias A, Zimicz AN (2014) Paleogene land mammal faunas of South America; a response to global climatic changes and indigenous floral diversity. J Mammal Evol 21:1-73 